\title{
ESTUDO DE FATORES QUE INFLUENCIAM O PROCESSO DE TRANSFORMAÇÃO GENÉTICA EM CITROS VIA Agrobacterium tumefaciens
}

JANAYNNA MAGALHÃES BARBOSA

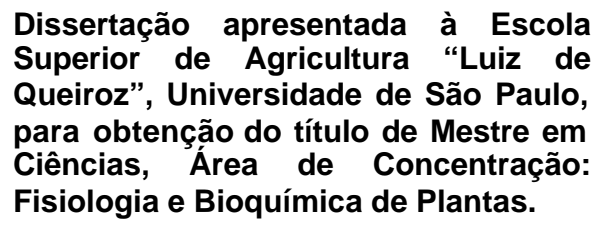

PIR A C I C A B A

Estado de São Paulo - Brasil

Maio - 2002 


\section{ESTUDO DE FATORES QUE INFLUENCIAM O PROCESSO DE TRANSFORMAÇÃO GENÉTICA EM CITROS VIA Agrobacterium tumefaciens}

JANAYNNA MAGALHÃES BARBOSA

Engenheiro Agrônomo

Orientadora: Profa. Dra. BEATRIZ MADALENA JANUZZI MENDES

Dissertação apresentada à Escola Superior de Agricultura "Luiz de Queiroz", Universidade de São Paulo, para obtenção do título de Mestre em Ciências, Área de Concentração: Fisiologia e Bioquímica de Plantas.

PIR A C I C A B A

Estado de São Paulo - Brasil

Maio - 2002 


\title{
Dados Internacionais de Catalogação na Publicação (CIP)
} DIVISÃO DE BIBLIOTECA E DOCUMENTAÇÃO - ESALQ/USP

\author{
Barbosa, J a naynna Magalhães \\ Estudo de fatores que influenciam o processo de transformação \\ genética em citros via Agrobacterium tumedaciens / J anaynna \\ Magalhã es Ba rbosa. - - Pira cicaba, 2002. \\ 51 p. : il. \\ Dissertação (mestrado) - - Escola Superior de Agricultura Luiz de \\ Queiroz, 2002. \\ Bibliografia. \\ 1. Agrobacterium 2. Frutas cítric as 3. Melhoramento genétic o vegetal \\ 4. Transformação genética 5. Transferência de genes 6 . Variedades \\ vegetais I. Título \\ CDD 634.3
}

"Permitida a cópia total ou parcial deste documento, desde que citada a fonte - $\mathrm{O}$ autor" 
À minha mãe Lorene e à minha avó Balduína pela vida, pelo amor e carinho dedicados e pelo exemplo de vida, que muito tem me dado força durante minha caminhada.

\section{DEDICO}




\section{AGRADECIMENTOS}

À Profa. Dra Beatriz Madalena Januzzi Mendes pela oportunidade, pela orientação, confiança e amizade;

Ao Prof. Dr. Francisco A. A. Mourão Filho pela colaboração durante a realização deste trabalho;

À Profa. Dra. Adriana P. M. Rodriguez pelo apoio profissional e pela amizade prestados durante este período;

À Profa. Dra. Beatriz Appezzato-da-Glória pela colaboração durante a realização do trabalho;

À farmacêutica Marli Kasue Misaki Soares, técnica do Laboratório de Anatomia Vegetal do Departamento de Ciências Biológicas da Escola Superior de Agricultura "Luiz de Queiroz" pelo auxílio nas técnicas de microscopia;

Aos colegas de laboratório e de curso Fernanda, Sandra, Nailton, Carol, Raquel, Girlene, Flávio, Paulo Celso, Lílian, Welinton, Márcia, Cantídio, Maria Graziela, Regina, Mariza, Raul, Chryz e Amaral pelo convívio e amizade, e auxílio prestado;

Ao Rafael R. Vasconcelos pelo auxílio nas análises estatísticas, pela solicitude e principalmente pela amizade;

Às amigas Liliane, Adriana, Daniela, Hérika e Nívea pelo apoio nos momentos difíceis, pelas conversas e rizadas;

À Joanne pelo apoio em casa, pelo companheirismo, amizade e dedicação;

À Kelly, Mônica e Juliana, minhas amigas queridas, pela amizade sincera e pelo apoio em todas as minhas decisões, mesmo à distância;

Aos amigos do COEM pela convicência e por me ensinar a ter humildade, paciência e resignação perante os acontecimentos da vida;

Ao Gabriel, D. Marli e S. Camillo, pelo apoio quando ainda não tinha bolsa; 
À minha família, pela compreensão nos momentos de ausência, pelo apoio incessante e pelo amor dedicado;

Ao meu irmão querido, Miguel Angelo, pelo apoio, amor e carinho;

Ao Luís Carlos Timm pela compreessão, apoio, amizade e carinho dedicados;

À Escola Superior de Agricultura "Luiz de Queiroz", pela oportunidade de realização do curso de mestrado;

À Capes, pelo suporte através de concessão de bolsa de estudo de mestrado e à Fapesp pelo auxílio financeiro à execução do projeto. 


\section{SUMÁRIO}

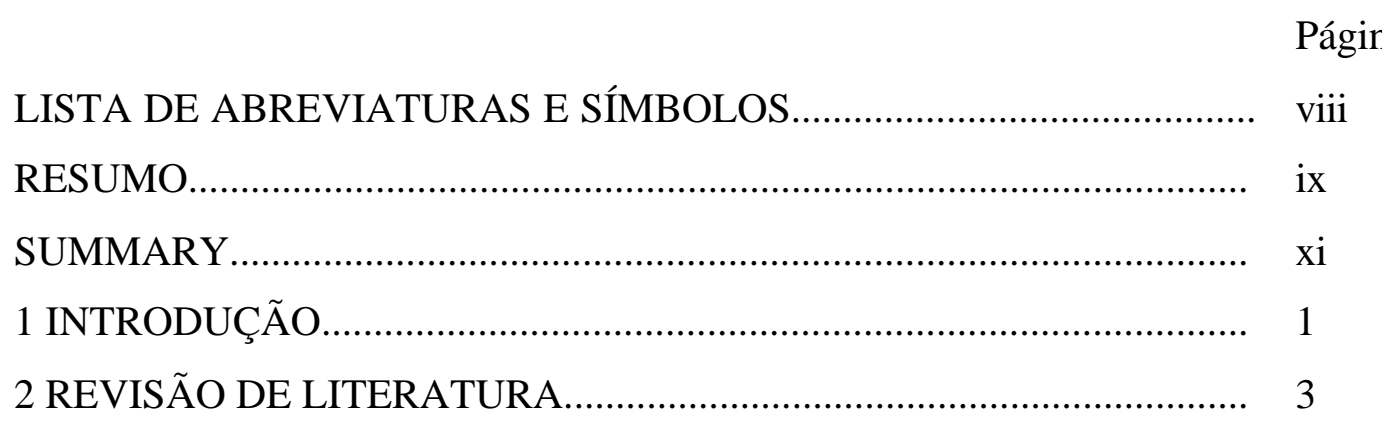

$2.1 \mathrm{O}$ sistema de transferência de genes por Agrobacterium......................... 3

2.2 Cultura de tecidos em citros................................................................. 6

2.3 Biotecnologia no melhoramento de citros.............................................. 9

2.3.1 Hibridação somática........................................................................... 10

2.3.2 Transformação genética................................................................. 11

2.4 Fatores que afetam a transformação genética via Agrobacterium tumefaciens....................................................................................... 14

3 MATERIAL E MÉTODOS................................................................ 16

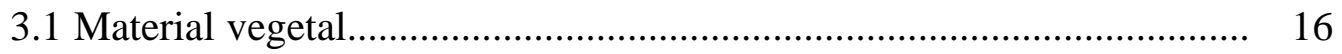

3.2 Manutenção e cultivo de A. tumefaciens................................................ 16

3.3 Transformação genética e regeneração de plantas................................... 17

3.4 Análise estatística ............................................................................... 19

3.5 Análise histológica associada ao teste histoquímico GUS...................... 19

4 RESULTADOS E DISCUSSÃO............................................................ 20

4.1 Fatores relacionados a indução dos genes vir......................................... 20

4.2 Fatores relacionados ao tipo de explante e condição de incubação pós

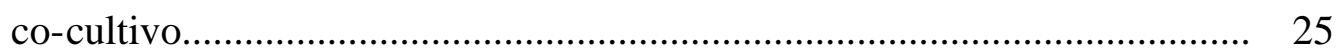




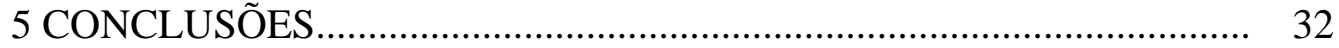

REFERÊNCIAS BIBLIOGRÁFICAS.............................................. 33 


\section{ABREVIATURAS E SÍMBOLOS}

\begin{tabular}{|c|c|}
\hline$\mu \mathrm{M}$ & Micromolar \\
\hline $35 \mathrm{~S}$ & Promotor do vírus do mosaico da couve-flor \\
\hline $2 \mathrm{iP}$ & 2-isopentenil adenina \\
\hline 2,4-D & Ácido 2,4-diclorofenoxiacético \\
\hline AIA & Ácido indol acético \\
\hline AS & Acetoseringona \\
\hline BAP & 6-Benzilaminopurina \\
\hline CaMV & Vírus do mosaico da couve-flor \\
\hline céls $\mathrm{mL}^{-1}$ & Células por mililitro \\
\hline$G F P$ & Gene da 'green fluorescent protein' \\
\hline $\mathrm{g} \mathrm{L}^{-1}$ & Gramas por litro \\
\hline GNA & Gene da Galanthus nivalis aglutininina \\
\hline IBA & Ácido indol butírico \\
\hline $\mathrm{Kb}$ & quilobase \\
\hline$m g L^{-1}$ & Miligramas por litro \\
\hline MS & Meio de cultura definido por Murashige \& Skoog (1962) \\
\hline NAA & Ácido naftaleno acético \\
\hline nptII & Gene da neomicina fosfotransferase \\
\hline $\mathrm{pb}$ & Pares de bases \\
\hline pTi & Plasmídeo indutor de tumor \\
\hline pRi & Plasmídeo indutor de raízes \\
\hline uidA & Gene codante da enzima $\beta$-glucuronidase \\
\hline $\mathrm{x}$-gluc & 5-bromo-4-cloro-3-indolil- $\beta$-D-glucuronideo cicloexilami \\
\hline
\end{tabular}




\title{
ESTUDO DE FATORES QUE INFLUENCIAM O PROCESSO DE TRANSFORMAÇÃO GENÉTICA DE CITROS VIA Agrobacterium tumefaciens
}

\author{
Autora: Janaynna Magalhães Barbosa \\ Orientadora: Profa. Dra. Beatriz Madalena Januzzi Mendes
}

\section{RESUMO}

A transformação genética está se tornando uma importante ferramenta, dentro dos programas de melhoramento genético de citros, e uma alternativa para contornar barreiras naturais da espécie, que dificultam o desenvolvimento de novas variedades pelo melhoramento convencional. Entretanto, os protocolos utilizados para transformação genética de citros têm resultado num baixo número de plantas transgênicas. Com o objetivo de estudar fatores que possam influenciar o processo de transformação genética de citros via Agrobacterium tumefaciens analisou-se o efeito do uso de acetoseringona em diferentes etapas do processo, as condições de incubação dos explantes durante e após o período de co-cultivo e o tipo de corte do explante. Foram utilizados segmentos de epicótilo de plântulas germinadas in vitro da variedade de laranja doce 'Hamlin' (Citrus sinensis L. Osbeck.) e da variedade citrange 'Carrizo' ( $C$. sinensis x Poncirus trifoliata Raf.), inoculados com a estirpe EHA 105 de A. tumefaciens, contendo o plasmídeo p35SGUSINT, com o gene de seleção que codifica a enzima neomicina fosfotransferase II (nptII) e o gene repórter uidA que codifica a enzima $\beta$-glucuronidase $(\mathrm{g} u s)$. O protocolo básico para transformação genética foi com a inoculação dos explantes por 20 minutos, com o período de co-cultivo de 3 dias em meio de cultura suplementado com acetoseringona $(100 \mu \mathrm{M})$ e transferidos para meio de cultura de seleção, constituído de meio de cultura EME, suplementado com BAP 
(1 $\left.\mathrm{mg} \mathrm{L}^{-1}\right)$, canamicina $\left(100 \mathrm{mg} \mathrm{L}^{-1}\right)$ e cefotaxime $\left(500 \mathrm{mg} \mathrm{L}^{-1}\right)$. As avaliações foram realizadas após 5-6 semanas de incubação, determinando-se o número de explantes com gemas adventícias, o número de gemas adventícias $g u s^{+}$e calculando-se a eficiência de transformação genética, definida pela relação entre o número de gemas gus ${ }^{+}$regeneradas e o número de explantes inoculados. Pelos resultados obtidos pôde-se observar uma maior eficiência de transformação genética para a variedade citrange 'Carrizo'; e que a eficiência da transformação genética aumentou, principalmente para a variedade de laranja doce 'Hamlin', quando a incubação do material durante o período de co-cultivo foi feita sob temperaturas inferiores a $27^{\circ} \mathrm{C}$. A suplementação do meio de cultura de cocultivo com acetoseringona depende do $\mathrm{pH}$ deste meio de cultura. A utilização de explantes seccionados longitudinalmente não se mostrou favorável devido ao crescimento excessivo da bactéria na superfície do explante. 


\title{
STUDY OF FACTORS THAT INFLUENCE THE CITRUS GENETIC TRANSFORMATION PROCESS VIA Agrobacterium tumefaciens
}

\author{
Author: Janaynna Magalhães Barbosa \\ Adviser: Profa. Dra. Beatriz Madalena Januzzi Mendes
}

\section{SUMMARY}

Genetic transformation is an important biotechnological tool in citrus genetic breeding programs, and an alternative to overcome natural barriers to the development of new varieties, by conventional breeding. However, the protocols used for citrus genetic transformation have resulted in a low number of transgenic plants. Therefore, this research evaluated some factors that might influence citrus genetic transformation process via Agrobacterium tumefaciens, such as: the addition of acetosyringone in different steps of the process, the explant incubation conditions during and after the period of co-cultivation, and the explant type cut. Epicotyl segments from seedlings of 'Hamlin' sweet orange (Citrus sinensis L. Osbeck) and 'Carrizo' citrange (C. sinensis L. Osbeck x Poncirus trifoliata Raf.) were inoculated with EHA 105 strain of A. tumefaciens harboring the binary plasmid p35SGUSINT containing the selection gene for neomicyn phosphotransferase II (nptII) and the reporter gene uidA for $\beta$ glucuronidase $(G U S)$. The basic protocol for genetic transformation included the explant inoculation for 20 minutes, and 3 days of co-cultivation in the culture medium supplemented with acetosyringone $(100 \mu \mathrm{M})$. The epicotyl segments were transferred to selection culture medium, EME culture medium supplemented with BAP $\left(1 \mathrm{mg} \mathrm{L}^{-1}\right)$, kanamycin $\left(100 \mathrm{mg} \mathrm{L}^{-1}\right)$ and cefotaxime $\left(500 \mathrm{mg} \mathrm{L}^{-1}\right)$. The evaluations were done after 
5-6 weeks of incubation, determining the number of explants with shoots, the number of $\mathrm{gus}^{+}$shoots, and calculating the genetic transformation efficiency, defined by the relation between the number of $g u s^{+}$shoots and the number of inoculated explants. The highest genetic transformation efficiency was observed in 'Carrizo' citrange. An increase of genetic transformation efficiency, mainly for the 'Hamlin' sweet orange occurred when the segments were incubated under temperatures below $27{ }^{\circ} \mathrm{C}$. The supplementation of the co-cultivation culture medium with acetosyringone depends on $\mathrm{pH}$ value of itself. The use of explant sectioned did not favor transformation, probably due to the excessive bacterial growth on explant surface. 


\section{INTRODUÇÃO}

Os citros são plantas de clima tropical e subtropical, que apresentam melhores qualidades em regiões subtropicais, podendo ser cultivados a partir do Equador até latitudes de $44^{\circ}$ norte ou sul (Simão, 1998). Entretanto, as principais áreas produtoras concentram-se em regiões subtropicais, em latitudes superiores a $20^{\circ} \mathrm{N}$ ou $20^{\circ} \mathrm{S}$ (Soost \& Cameron, 1975).

O Brasil é o maior produtor de laranja do mundo, seguido pelos EUA. Na safra 2000/2001 o Brasil produziu cerca de 14.484 .000 toneladas métricas de laranja (FNP, 2002), sendo que deste total o estado de São Paulo é responsável por $80 \%$. Porém, o fruto in natura tornou-se um produto secundário, pois a produção do suco de laranja concentrado e congelado para exportação tem crescido bastante, sendo que quase $100 \%$ da produção é comercializada com outros países. Em 2000, foram exportadas 793.600 toneladas métricas de suco de laranja, enquanto o volume comercializado para laranja in natura foi de 75.000 toneladas.

A distribuição das áreas de plantio é muito irregular ao redor do globo. Apenas dois, entre mais de cem países produtores de citros, detêm mais da metade da produção mundial, o Brasil e os Estados Unidos (FAO, 2001).

No Brasil, nos últimos anos, uma grande parte da área cultivada com espécies cítricas vem sendo substituída pelo cultivo da cana-de-açúcar, principalmente no estado de São Paulo, devido a disseminação de doenças como o cancro cítrico e a clorose variegada dos citros (CVC), fato que pode ser comprovado pela diminuição da produção de citros no ano de 2001 (FNP, 2002).

Além de problemas com doenças e pragas, o melhoramento de citros se torna uma prática difícil devido a características relacionadas com a biologia reprodutiva do gênero. Como principais limitações ao melhoramento de citros podemos citar: 
esterilidade de óvulo e pólen, autoincompatibilidade, poliembrionia, alta heterosigosidade e longo período de juvenilidade (Gmitter et al., 1992).

O desenvolvimento de técnicas de biotecnologia tem oferecido novas alternativas para o melhoramento dos citros. Dentre estas técnicas, a transformação genética vêm mostrando ter um grande potencial, por tornar possível a introdução de genes que modificam características de interesse agronômico, mantendo-se as características originais da variedade e evitando-se a transferência de características deletérias (Vardi et al., 1990; Kaneyoshi et al., 1994; Peña et al., 1995a).

O objetivo do trabalho bi estudar o efeito de diferentes fatores, relacionados ao explante, condição de incubação e cultivo de Agrobacterium, na eficiência de regeneração de plantas transformadas, pelo cultivo in vitro de segmentos de epicótilo de citrange 'Carrizo'(Citrus sinensis L. Osbeck. x Poncirus trifoliata Raf.) e laranja doce 'Hamlin' (Citrus sinensis L. Osb.), a fim de otimizar o protocolo de transformação genética de citros via Agrobacterium tumefaciens. 


\section{REVISÃO DE LITERATURA}

\subsection{O sistema de transferência de genes por Agrobacterium}

Agrobacterium é uma bactéria fitopatogênica do solo, tipo bacilo aeróbico, gram negativo, pertencente a família Rhizobiaceae que compreende, entre outros, os gêneros Rhizobium, Bradyrhizobium e Phyllobacterium, que são bactérias fixadoras de nitrogênio (Lipp-Nissinen, 1993).

Dentro do gênero Agrobacterium, A. tumefaciens e A. rhizogenes são conhecidas como patógenos de plantas, causando a doença conhecida como galha da coroa (Smith \& Townsend ${ }^{1}$ ) e a síndrome da raiz em cabeleira (Riker et al. ${ }^{2}$ ), citados por Van Sluys (1999).

$\mathrm{Na}$ natureza, um fragmento de DNA, parte do plasmídeo bacteriano, é transferido e integrado no genoma de células de plantas infectadas (Lee et al., 1995; Vicedo et al., 1996). No fragmento de DNA (T-DNA-'Transferred DNA') que é transferido para a célula vegetal estão genes que codificam enzimas envolvidas na síntese de opinas e de fitohormônios (Nam et al., 1997; Tinland, 1996), produtos que são responsáveis pela formação do tumor e sobrevivência da bactéria.

Os hormônios vegetais sintetizados, ácido indol acético (auxina) e isopentenilAMP (citocinina), induzem um desbalanço hormonal, que tem como conseqüência uma multiplicação descontrolada das células transformadas, assim como das células vizinhas, resultando na formação do tumor. Cultivando-se tecidos infectados in vitro, foram detectadas substâncias específicas nunca antes encontradas em tecidos vegetais (Lioret ${ }^{3}$ ),

${ }^{1}$ SMITH, E.; THOWNSEND, C. A plant tumor of bacterial origin. Science, v.24, p.671-673, 1907.

${ }^{2}$ RIKER, A.; BANFIELD, W.; WRIGHT,W.; KEITT, G.; SAGEN, H. Studies on infectious hairy root of nursery apple trees. Journal Agricultural Research, v.41, p.887-890, 1930.

${ }^{3}$ LIORET, C. Les acides amines libres ds tissues de crown gall. Mise en evidence d'un acide amine particulier à ces tissues. Comptes Rendus Hebdomadaires des Seances de l'Academie des Sciences, v.244, p.2171-2174, 1957. 
citado por Van Sluys (1999). Estas substâncias foram denominadas opinas e estão especificamente relacionadas com a estirpe bacteriana inoculada (Dessaux et al., 1993). Assim, o patógeno Agrobacterium cria para si um nicho favorável, pela modificação genética das células da planta, sendo este processo denominado "colonização genética" (Hooykaas \& Beijersbergen, 1994) e assim, as estirpes de Agrobacterium são classificadas de acordo com o tipo de opina produzida. As opinas estão agrupadas em quatro famílias: octopina, nopalina, manopina e agrocinopina, tendo sido identificados cerca de 20 tipos de opinas (Weising \& Kahl, 1996).

O plasmídeo Ti pode ser dividido em duas regiões, uma metade que possui o T-DNA (que abriga os oncogenes-onc) e a região de virulência-vir, que é indispensável para a transferência do T-DNA, e a outra metade que compreende os genes de replicação e incompatibilidade (ori/inc), função de conjugação ( $r a$ ) (Clare \& McClure, 1995), região de catabolismo de opina $(o p c)$, sendo que nenhuma delas é necessária à virulência (Hooykaas \& Beijersbergen, 1994; Van Sluys et al., 1992).

A região-T ou T-DNA ('Transferred DNA'), é a única parte do plasmídeo transferida para a célula vegetal. Os limites do T-DNA são definidos por $25 \mathrm{pb}$ diretamente repetidos em cada extremidade, e definem a porção do plasmídeo que será transferida (Van Sluys, 1999). A presença da borda direita é essencial para que a transferência ocorra (Wang et al., 1984).

A região responsável pelo processo de transferência é denominada de região de virulência (vir). Essa região é ativada por compostos fenólicos liberados pelos tecidos vegetais lesados, iniciando o processo de transferência do T-DNA para a célula vegetal (Stachel et al., 1985; Van Sluys, 1999).

A região de virulência contendo os genes vir do plasmídeo forma um conjunto de operons corregulados pelas mesmas proteínas. Estas unidades transcricionais denominadas virA, virB, virC, virD, virE e virG possuem um tamanho de aproximadamente $40 \mathrm{~Kb}$, estando localizadas adjacente à borda esquerda do T-DNA (Hooykaas \& Beijersbergen, 1994). Somente quatro locos vir são absolutamente essenciais para a formação do tumor ( $\operatorname{vir} A$, $\operatorname{vir} B, \operatorname{vir} G$ e $\operatorname{vir} D$ ), enquanto os outros afetam somente a eficiência de transferência (Weising \& Kahl, 1996). Os plasmídeos tipo octopina possuem operons $\operatorname{virF}$ e virH e os tipo nopalina perderam virF e virH e contêm 
um outro, denominado tzs (trans-zeatinsintetase). Todos os locos vir são induzidos na presença de compostos fenólicos e alguns monossacarídeos (Hooykaas \& Beijersbergen, 1994).

O processo de transferência do T-DNA pode ser divido em duas etapas: uma etapa bacteriana e uma etapa vegetal. A etapa bacteriana inclui eventos que levam à produção e exportação de um vetor funcional contendo a informação genética do TDNA. A etapa vegetal inclui os eventos que ocorrem dentro da célula vegetal até o momento da integração do DNA bacteriano no genoma nuclear da planta (Tinland, 1996).

Após a indução da expressão dos genes vir, uma molécula de DNA linear de fita simples (fita-T) é produzida, sendo que as bordas repetidas (25pb) podem ser usadas para iniciar e terminar a produção da fita-T (Hooykaas \& Beijersbergen, 1994; Zambryski, 1992). A fita $\mathrm{T}$ é transferida para o núcleo da célula vegetal como um complexo proteína-DNA (complexo-T) (Weising \& Kahl, 1996; Zupan \& Zambryski, 1997).

A primeira demonstração de que esta interação, bactéria-planta, poderia resultar em sistemas eficientes de transformação em plantas foi a introdução do gene que confere resistência ao antibiótico canamicina em plantas de fumo (Herrera-Estrella et al., 1983), confirmando a possibilidade de manipulação do plasmídeo de Agrobacterium, permitindo assim, a passagem de uma informação genética desejada para o interior de uma célula hospedeira (Van Sluys, 1999).

Os vetores utilizados para sistemas de transformação são vetores chamados desarmados, isto é, não possuem os oncogenes em seu plasmídeo, mas retém os genes de virulência (região vir), localizados no plasmídeo Ti e os genes do cromossomo bacteriano (chv, pscA e att) (Klee et al., 1987). Estas construções de plasmídeos possuem promotores de plantas e genes bacterianos que conferem resistência a drogas ou antibióticos, fazendo com que estes marcadores sejam eficientes para a seleção de células ou plantas transformadas.

Os vetores podem ser divididos em dois tipos: cointegrado (sistema in cis) no qual os genes vir e o T-DNA modificado estão no mesmo replicon (Zambryski et al., 1983) e binário (sistema in trans), onde o T-DNA modificado é mantido em um 
plasmídeo distinto do Ti (Hoekema et al., 1983).

\subsection{Cultura de tecidos em citros}

Os primeiros trabalhos de cultura de tecidos em citros foram realizados com o objetivo de produzir plantas isentas de vírus a partir do cultivo in vitro de tecido nucelar, obtendo-se embriões nucelares a partir de espécies monoembriônicas (Rangan et al., 1968).

O resultado destes trabalhos incentivaram a utilização da cultura de tecidos não apenas na obtenção de plantas livres de vírus, mas no aperfeiçoamento destas técnicas visando obter plantas sadias e vigorosas, e para obtenção de novas variedades, a partir das técnicas de hibridação somática e transformação genética (Kobayashi \& Uchimiya, 1989; Peña et al., 1995a; 1995b; Cervera et al., 1998a;1998b).

Em cultura de tecidos de citros, o calo embriogênico é normalmente o material mais utilizado, podendo ser obtido a partir de tecido nucelar, retirado de sementes imaturas de frutos jovens (Vu et al., 1993; Oliveira et al., 1994) ou de óvulos não fertilizados, retirados de frutos maduros (Moore 1985; Kunitake et al., 1991). A eficiência na obtenção de calos é normalmente baixa e dependente do genótipo, do meio de cultivo e do tipo de explante utilizado (Kochba et al., 1972). Uma vez obtidos os calos, estes podem ser cultivados por longos períodos, mantidos em meio de cultura adequado, de preferência na ausência de reguladores vegetais, devido ao fato destes provocarem variação somaclonal em caso de exposições prolongadas (Illg, 1990).

As suspensões celulares são obtidas cultivando-se calos friáveis em meio de cultura líquido incubados sob agitação contínua (Dixon, 1985; Cabasson et al., 1997), podendo ser uma boa alternativa para aumentar a quantidade de células embriogênicas num curto espaço de tempo.

A regeneração de plantas a partir de calos ou de células em suspensão ocorre via embriogênese somática (Cabasson et al., 1997) ou via organogênese. A presença de auxinas, citocininas ou giberilinas inibem a embriogênese somática em citros. Desta forma, a indução da embriogênese somática é realizada utilizando-se compostos inibidores de auxinas (Kochba et al., 1977) e giberilinas e diferentes fontes de carboidrato (Spiegel-Roy \& Saad, 1986; Tomaz et al., 2001). Calos (Vardi et al., 1982; 
Kobayashi et al., 1983) e cultura de células em suspensão (Kobayashi et al., 1985; Grosser \& Gmitter Junior, 1990) na maioria dos protocolos, são os materiais mais utilizados para obtenção de protoplastos.

A regeneração de plantas no cultivo in vitro de citros pode também ocorrer via organogênese, quando se utiliza explantes não meristemáticos como segmento de epicótilo ou segmento internodal.

Podemos definir organogênese como sendo o processo pelo qual células e tecidos são induzidos a sofrer mudanças que levam a formação de uma estrutura monopolar, podendo ser uma estrutura caulinar ou radicular, cujo sistema vascular se encontra freqüientemente conectado ao explante de origem (Thorpe, 1994).

A regeneração de plantas pela organogênese in vitro pode ocorrer de forma indireta, com a formação de calos na região do corte antes da formação do órgão, ou de forma direta, onde não há formação de calos, mas apenas uma proliferação celular restrita às regiões seccionadas do explante, apresentando uma zona de intensa atividade meristemática (Handro \& Floh, 1990).

Em cultura de tecidos, o controle da organogênese in vitro, é feito pela introdução exógena de sinais e de substratos diversos. A retirada de um fragmento de tecido a partir de um organismo íntegro e sua introdução em meio de cultura contendo nutrientes e reguladores vegetais traz como conseqüência a liberação de suas células do controle a que estavam submetidas nesse organismo, expondo-as a uma nova condição, onde a capacidade de divisão pode ser readquirida (desdiferenciação) e o genoma pode expressar-se de novas formas, conduzindo-as a novos padrões de diferenciação (Handro \& Floh, 1990).

A resposta organogênica pode variar de acordo com a espécie, idade, posição do explante, época do ano (Barlass \& Skene, 1982), composição do meio de cultura e condições de incubação (Pérez-Molphe-Balch \& Ochoa-Alejo, 1997).

A regeneração via organogênese em Citrus, tem sido descrita para vários tecidos incluindo raízes (Bhat et al., 1992; Sauton et al., 1982; Sim et al., 1989; Edriss \& Burger, 1984; Goh et al., 1995), discos de folha (Chaturvedi \& Mitra, 1974), segmento internodal (Barlass \& Skene, 1982; Durán-Vila et al., 1989; Moore, 1986), segmento de cotilédone (Sim et al., 1989; Goh et al., 1995), segmento de epicótilo (Sim et al., 1989; 
Edriss \& Burger, 1984; Goh et al., 1995; Magon \& Singh, 1995; García-Luis et al., 1999; Moreira-Dias et al., 2000) ou de hipocótilo (Magon \& Singh, 1995).

Variações consideráveis tem sido relatadas com relação a resposta das culturas de citrus na morfogênese, estas variações podem ocorrer devido a diferenças genotípicas ou quanto a natureza do explante (Durán-Vila et al., 1989; Gmitter et al., 1992; Goh et al., 1995; Pérez-Molphe-Balch \& Ochoa-Alejo, 1997).

Podemos verificar na literatura que diversos trabalhos foram realizados na tentativa de otimizar os protocolos de regeneração seja para obtenção de clones ou para introdução em programas de transformação genética. No início dos estudos em organogênese, houve uma preocupação em obter uma concentração ideal para manter o balanço citocinina/auxina (Edriss \& Burger, 1984; Durán-Vila et al., 1992; Moreira-Dias et al., 2000) na tentativa obter uma maior eficiência de regeneração. Alguns trabalhos mostram bons resultados utilizando combinações de BAP com NAA (Durán-Vila et al., 1992; Moreira-Dias et al., 2000), porém existem relatos de que o NAA inibe a organogênese em algumas espécies de Citrus (Edriss \& Burger, 1984; Moore et al., 1986).

A citocinina BAP tem mostrado melhores resultados em organogênese direta ou indireta, e vem sendo utilizada em concentrações variando entre $0,5-1,0 \mathrm{mg} \mathrm{L}^{-1}$ para variedades de laranja doce, 2,5 $\mathrm{mg} \mathrm{L}^{-1}$ para limão 'Cravo' (Moura et al., 2001) e de 2,0 $\mathrm{mg} \mathrm{L}^{-1}$ em Poncirus trifoliata (Pasqual \& Ando, 1989).

Moura et al. (2001) mostram que explantes de laranja 'Pêra' apresentaram maior número de gemas por explante quando utilizaram a citocinina BAP na concentração de 1 e $2 \mathrm{mg} \mathrm{L}^{-1}$. Porém, o uso de altas concentrações de citocininas pode inibir a formação de gemas (Edriss \& Burger et al., 1984)

Muitos estudos tem focalizado a obtenção de uma composição ideal do meio de cultura, entretanto, a temperatura de incubação e a taxa de radiação fotossintética também influenciam o desempenho da cultura de tecidos in vitro (Durán Vila et al., 1992).

Durán-Vila et al. (1992) conseguiram melhores resultados de regeneração quando os explantes de laranja doce foram incubados à temperatura de $27{ }^{\circ} \mathrm{C}$, e a formação de gemas diminuiu drasticamente quando esta temperatura foi elevada. 
Quando os explantes foram incubados no escuro houve um aumento na eficiência de organogênese indireta. Mas, existem resultados mostrando alta eficiência de transformação quando segmentos internodais de C. reticulata Blanco (Pérez-MolpheBalch \& Ochoa-Alejo, 1997) ou segmentos de epicótilo de citrange 'Troyer' (MoreiraDias et al., 2000) foram incubados sob fotoperíodo de 16-h de luz. Uma vantagem da incubação no escuro é o aumento do tamanho das gemas regeneradas e sua maior eficiência de enraizamento na ausência de auxinas (Moreira-Dias et al., 2000).

Existem também diferenças na resposta com relação ao grau de maturidade do tecido, onde o tecido maduro responde melhor com concentrações mais baixas de BAP, em segmentos internodais de citrange 'Carrizo' (Barlass \& Skene, 1982). Porém na maioria dos trabalhos com tecido maduro houve uma freqüência de regeneração muito baixa ou quase nula (Sim et al., 1989; Bhat et al., 1992), sendo que as mais altas taxas de regeneração têm sido obtidas a partir de tecido juvenil (Edriss \& Burger, 1984; Goh et al., 1995; Moreira-Dias et al., 2000; Pérez-Molphe-Balch \& Ochoa-Alejo, 1997; Moura et al., 2001).

Estas muitas diferenças no comportamento dos citros podem estar relacionadas à posição do explante no meio de cultura (Moreira-Dias et al. 2000). García-Luis et al. (1999) mostraram que segmentos de citrange 'Troyer' inseridos verticalmente no meio respondem de forma diferente daqueles explantes cultivados horizontalmente, sendo esta última a melhor posição para regeneração de gemas. Resultados similares foram obtidos com segmentos seccionados longitudinalmente e incubados com a região do corte em contato com o meio de cultura (Pérez-Molphe-Balch \& Ochoa-Alejo, 1997; Ghorbel et al., 1998; Moreira et al., 2001).

Todas estas variações na resposta dos citros ao cultivo in vitro, chamam a atenção para a necessidade de obtenção de um sistema de regeneração eficiente via organogênese para o estabelecimento de protocolos de transformação genética para estas espécies (Moreira-Dias et al., 2000).

\subsection{Biotecnologia no melhoramento de citros}

A incorporação de técnicas de biotecnologia em programas de melhoramento de citros, permite facilitar e acelerar a utilização da variabilidade disponível (Grosser \& 
Gmitter Junior, 1990) bem como utilizar germoplasma ainda não explorado (Grosser et al., 1996), criando assim, novas combinações que poderão ser incluídas em programas de melhoramento convencional, ou resultar em variedades novas (Gmitter Junior et al., 1992).

\subsubsection{Hibridação somática}

A fusão de protoplastos é uma forma alternativa para a produção de híbridos de espécies e gêneros sexualmente incompatíveis (Kobayashi \& Ohgawara, 1988). Em citros a hibridação somática via fusão de protoplastos se aplica tanto ao melhoramento de variedades copa como porta-enxerto (Grosser et al., 1988a).

O termo "protoplasto" é normalmente usado para descrever células vegetais desprovidas de parede celular. As células vegetais neste estado transitório, podem ser manipuladas à semelhança das células animais e microorganismos, conservando ainda as potencialidades das células ve getais completas (Carneiro et al., 1998).

O primeiro isolamento e cultivo de protoplastos totipotentes em citros foi realizado com laranja 'Shamouti', porém foi obtido somente a regeneração de embriões somáticos que não se converteram em plantas (Vardi et al., 1975).

Protoplastos de citros têm sido isolados a partir de calos (Vardi et al., 1975; 1982; Kobayashi et al., 1983), cultura de células em suspensão (Kobayashi et al., 1985; Grosser \& Gmitter Junior, 1990), folhas (Grosser \& Gmitter Junior, 1990) e cotilédones (Burger \& Hackett, 1982).

O primeiro relato de hibridação somática em citros foi descrito por Ohgawara et al. (1985), produzindo um híbrido alotetraplóide pela fusão de protoplastos, com PEG (polietilenoglicol), isolados a partir de calos embriogênicos de Citrus sinensis e de folhas de Poncirus trifoliata. Desde então, outros trabalhos foram realizados, com o objetivo de produzir híbridos somáticos interespecíficos (Mourão Filho et al., 1996; Grosser at al., 1998a; Mendes-da-Glória et al., 2000; Mendes et al., 2001), híbridos somáticos intergenéricos com parentais sexualmente compatíveis (Ohgawara, 1985, Grosser et al., 1988a; Grosser et al. 1996; Louzada et al., 1992) e os híbridos intergenéricos de Citrus com parentais sexualmente incompatíveis (Grosser et al. 1988b; 1996; Motomura et al., 1995), de variedades copa e porta-enxerto com o intuito de 
aproveitar características relacionadas a resistência ao frio, tolerância a solo salino e resistência a doenças.

Kobayashi et al. (1991) relataram que híbridos somáticos em condições de campo apresentam bom desenvolvimento com fertilidade de óvulo e pólen. Algumas combinações têm demonstrado uma redução no porte das árvores como tangerina 'Cleopatra' + citrumelo 'Swingle' e laranja azeda + limão 'Cravo' (Grosser et al., 1998b). Os híbridos de laranja azeda + lima doce 'Palestina' e laranja azeda + citrange 'Carrizo' mostraram resistência ao vírus da tristeza, apresentaram bom desempenho no campo e estão produzindo frutos com semente (Grosser et al., 2000). Híbridos somáticos contendo o parental trifoliata 'Flying Dragon' possuem grande potencial para redução do porte de árvores e na precocidade de produção, além dessas características, plantas enxertadas sobre estes híbridos, geralmente produzem frutos maiores do que aquelas enxertadas sobre trifoliata 'Flying Dragon' (Grosser et al., 1998b).

\subsubsection{Transformação genética}

Dentre os métodos de transformação genética existentes, a introdução direta de DNA em protoplastos e a transformação mediada por Agrobacterium tem sido os mais utilizados na obtenção de plantas de citros transgênicas (Moore et al., 1992; Fleming et al., 2000).

O primeiro relato de transformação genética em citros foi feito por Kobayashi \& Uchimiya (1989), utilizando polietileno glicol (PEG) para introdução direta de DNA em protoplastos de laranja doce 'Trovita' (Citrus sinensis L. Osbeck).

Outros trabalhos de transformação genética em citros vem sendo realizados desde então, pelo tratamento com PEG em protoplastos de limão rugoso (Citrus jambhiri Lush.) (Vardi et al., 1990) e laranja doce 'Itaboraî' (Fleming et al., 2000), bombardeamento de partículas em células embriogênicas de tangelo (Yao et al., 1996) e pelo co-cultivo com Agrobacterium tumefaciens (Hidaka et al., 1990; Moore et al., 1992; Peña et al., 1995a; 1995b; 1997; Kaneyoshi et al., 1994; Cervera et al., 1998a; 1998b; Gutiérrez-E. et al., 1997; Bond \& Roose, 1998; Yang et al., 2000) e Agrobacterium rhizogenes (Pérez-Molphe-Balch \& Ochoa-Alejo, 1998).

Em trabalhos mais recentes o sistema mais utilizado para espécies cítricas tem 
sido o método de transformação indireto, mediado por Agrobacterium tumefaciens (Peña et al., 1995a; 1997; Gutiérrez-E. et al., 1997; Cervera et al., 1998a;1998b;1998c) utilizando diversos tipos de explantes (Moore et al., 1992; Pérez-Molphe-Balch \& Ochoa-Alejo, 1998; Moore et al., 1992; Kaneyoshi et al., 1994; Peña et al., 1995b; 1997; Cervera et al., 1998a;1998b; Bond \& Roose, 1998) e testando vários fatores que afetam a eficiência do processo (Durán-Vila et al., 1992; Kaneyoshi et al., 1994; Peña et al., 1995a; 1995b; Bond \& Roose, 1998;).

Na tentativa de aumentar a eficiência de transformação genética em citros, vários trabalhos foram realizados utilizando diferentes tipos de explantes: segmento internodal (Moore et al., 1992; Peña et al., 1995; Pérez-Molphe-Balch \& Ochoa-Alejo, 1998; Cervera et al., 1998a; Ghorbel et al.,1999), células em suspensão (Hidaka et al., 1990), protoplastos (Fleming et al., 2000) e segmentos de epicótilo (Moore et al., 1992; Kaneyoshi et al., 1994; Peña et al., 1997; Cervera et al., 1998b; 2000; Bond \& Roose, 1998, Yang et al., 2000).

Os métodos para transformação genética em citros utilizam em sua maioria tecido juvenil, porém existe um grande interesse em se utilizar tecido maduro para a obtenção de plantas transformadas, já que na transformação genética de tecido juvenil, as características só poderão ser avaliadas quando as plantas deixarem a fase juvenil, o que poderá demorar até 20 anos no caso de laranja doce (Cervera et al., 1998a). Cervera et al. (1998a) obtiveram plantas transformadas de laranja doce a partir de tecido maduro, porém com uma frequiência de regeneração menor do que aquela obtida a partir de tecido juvenil. Estas plantas obtidas estão em condições de casa-de-vegetação e apresentaram florescimento após 14 meses.

Várias estirpes de Agrobacterium têm sido testadas em citros, dentre elas, EHA 101 e EHA 105 (Peña et al., 1995a; 1995b; 1997; Gutiérrez-E. et al., 1997; Bond $\&$ Roose, 1998) mostraram melhores resultados. Quando a estirpe LBA 4404 foi testada para laranja doce e citrange 'Carrizo' não houve regeneração de plantas transgênicas (Bond \& Roose, 1998).

Ainda assim, a freqüência de regeneração de plantas transformadas proveniente de sistemas baseados em Agrobacterium tumefaciens tem sido baixa. A eficiência de transformação obtida em segmentos internodais de citrange 'Carrizo' foi de 2 \% (Moore 
et al. 1992), em laranja doce 7,9\% (Peña et al., 1995a) e em lima mexicana de 6,7\% (Peña et al., 1997). Além da baixa eficiência de regeneração de plantas transformadas, Moore et al., (1992) relatam sérias dificuldades no enraizamento das plantas obtidas.

Como solução ao problema de enraizamento tanto para plantas provenientes de tecidos juvenil ou maduro, tem sido proposta a enxertia in vitro de ápices meristemáticos sobre porta-enxertos vigorosos (Peña et al., 1995a; 1995b; 1997), o que tem aumentado o número final de plantas transformadas.

Os sistemas acima descritos, tem utilizado o gene GUS como gene repórter, mas o gene GFP já foi utilizado para citros (Ghorbel et al., 1999; Fleming et al., 2000). Como gene marcador de seleção o gene nptII tem sido mais utilizado em citros (Hidaka et al., 1990; Peña et al., 1995a; Gutiérrez-E. et al., 1997), porém a maioria dos trabalhos relatam a regeneração de uma grande porcentagem de escapes, mostrando que a canamicina restringe mas não inibe completamente a regeneração de gemas não transformadas (Peña et al., 1997).

Apesar da baixa eficiência de regeneração de plantas no sistema mediado por Agrobacterium, alguns genes de importância agronômica estão sendo introduzidos em citros com sucesso, como tolerância ou resistência ao vírus da tristeza dos citros pela introdução do gene da capa protéica do vírus da tristeza em laranja azeda (C. aurantium L.), lima (C. aurantifolia (Christm.) Swing) (Gutiérrez-E. et al., 1997) e em lima Mexicana (Domíngues et al., 2000), tolerância a salinidade pela introdução do gene HAL2 em citrange 'Carrizo' (Cervera et al., 2000), em grapefruit (Citrus paradisi Macf.) o gene GNA que confere resistência contra afídeos (Yang et al., 2000) e plantas de citrange 'Carrizo' expressando constitutivamente os genes LEAFY e APETALAl de Arabidopsis, que tiveram o período de juvenilidade diminuídos, florescendo já no primeiro ano de cultivo (Peña et al, 2001).

\subsection{Fatores que afetam a transformação genética via Agrobacterium tumefaciens:}

Além de um protocolo de regeneração in vitro seguro e eficiente, existem diversos outros fatores que podem afetar a eficiência da transformação genética via Agrobacterium tumefaciens. Dentre os fatores que afetam a eficiência de transformação via Agrobacterium estão o cultivo (Sarmento et al., 1992; Cervera et al., 1998b; Peña et 
al., 1995b; Confalonieri et al., 1995) e a estirpe de Agrobacterium (Holford et al., 1992; Gutiérrez-E. et al., 1997; Bond \& Roose, 1998), o tipo de explante, o genótipo (Pawlicki, et al., 1992; Jacq et al., 1993; Gutiérrez-E. et al., 1997), e as condições de incubação no co-cultivo (Jacq et al., 1993; Alt-Moerbe et al., 1988) e pós co-cultivo.

A adição de acetoseringona no meio de crescimento bacteriano apresentou efeitos positivos para a espécie arbórea Populus nigra L. (Confalonieri et al., 1995) e em Arabidopsis thaliana (Sheikholeslam \& Weeks, 1987), já no meio de co-cultivo não mostrou efeitos benéficos para beterraba (Jacq et al., 1993) e cenoura (Pawlicki et al., 1992), porém aumentou a frequiência de transformação em citrange 'Carrizo' (Cervera et al., 1998b), laranja doce (Bond \& Rose, 1998) e outras espécies de citros (Cervera et al., 1998b). Possivelmente algumas espécies já tenham compostos fenólicos endógenos suficientes para induzir a região vir, não havendo a necessidade de adicionar compostos sintéticos.

A adição de auxina no pré-cultivo em Arabidopsis thaliana (Sangwan et al., 1992) ou no co-cultivo com explantes de citrange 'Carrizo' (Cervera et al., 1998b), lima (Peña et al., 1997) e laranja azeda (C. aurantium L.) (Domínguez et al., 2000) resultou em uma melhoria da eficiência de transformação.

Alguns autores mencionam que o efeito combinado de acetoseringona com temperatura (Dillen et al., 1997; Kapila et al., 1997) e pH baixo (Holford et al., 1992; Sheikholeslam \& Weeks, 1987) tem mostrado um aumento na eficiência da transformação genética.

Em Nicotiana tabacum, a melhor temperatura de co-cultivo ficou entre 19-22 ${ }^{\circ} \mathrm{C}$ e $22^{\circ} \mathrm{C}$ para Phaseolus acutifolius A. Gray, mostrando que a transferência de T-DNA é dependente da temperatura (Dillen et al., 1997). Houve um efeito positivo em Arabidopsis thaliana quando adicionou-se acetoseringona ao meio de crescimento bacteriano com pH ajustado para 5,6 (Sheikholeslam \& Weeks, 1987). Estes resultados indicam que a indução da região vir é dependente de $\mathrm{pH}$ ácido $(5,0-5.7)$ na presença de acetoseringona (Alt-Moerbe et al., 1988). Em citros, o efeito do $\mathrm{pH}$ ainda não foi testado, porém Yang et al. (2000) diminuíram a temperatura de co-cultivo para $22{ }^{\circ} \mathrm{C}$ e adicionaram acetoseringona em todas as etapas do processo de transformação.

Durán-Vila et al. (1992) relataram primeiro a incubação de explantes 
internodais de laranja doce no escuro em meio de seleção. A exposição dos explantes ao escuro após o período de co-cultivo tem sido empregada para estimular a regeneração de gemas em citrange 'Carrizo' (Peña et al., 1995a), laranja doce (Peña et al., 1995b), lima (Peña et al., 1997) e outras espécies frutíferas lenhosas tais como maçã (Maheswaran et al., 1992; James et al., 1993) e pêra (Mourgues et al., 1996). Porém Kaneyoshi et al. (1994) relataram em seu trabalho uma alta freqüência de regeneração de $P$. trifoliata sem exposição dos explantes ao escuro.

Um fator chave parece ser uma fase de proliferação de calos transformados antes da indução de regeneração de gemas, o que poderia ser obtido pela combinação de um período de escuro longo e variação nas concentrações de reguladores vegetais (Mourgues et al., 1996). 


\section{MATERIAL E MÉTODOS}

\subsection{Material vegetal}

Sementes de citrange 'Carrizo' (Citrus sinensis L. Osbeck x Poncirus trifoliata L. Raf.) e laranja doce 'Hamlin' (Citrus sinensis L. Osbeck) extraídas de frutos maduros, tiveram sua casca retirada e foram submetidas a assepsia em uma solução 3:1 (água:hipoclorito de sódio), por 15 minutos. Após a assepsia, as sementes foram lavadas em água destilada esterilizada e introduzidas em tubos de ensaio contendo meio de cultura MS (Murashige \& Skoog, 1962) básico, sem adição de fitohormônios, com pH ajustado para 5,8. As sementes foram incubadas no escuro, a $27^{\circ} \mathrm{C}$, durante 4-6 semanas para germinação e alongamento do epicótilo. Após este período, as plântulas germinadas foram transferidas para condições de fotoperíodo de 16-h de luz, por um período de 7-10 dias, quando foram retirados os segmentos de epicótilo $(0,8-1,0 \mathrm{~cm})$.

\subsection{Manutenção e cultivo de Agrobacterium tumefaciens:}

A. tumefaciens EHA 105 (Hood et al., 1993) contendo o plasmídeo binário p35SGUSINT (Vancanneyt et al., 1990) foi mantida em solução $50 \%$ glicerol, a $-80^{\circ} \mathrm{C}$. A bactéria foi cultivada em meio de cultura YEP sólido (10 $\mathrm{g} \mathrm{L}^{-1}$ de peptona, $10 \mathrm{~g} \mathrm{~L}^{-1}$ de extrato de levedura, $5 \mathrm{~g} \mathrm{~L}^{-1}$ de $\mathrm{NaCl}$ e $15 \mathrm{~g} \mathrm{~L}^{-1}$ de ágar), contendo canamicina (50 mg $\mathrm{L}^{-1}$ ) e rifampicina $\left(50 \mathrm{mg} \mathrm{L}^{-1}\right)$, por $48 \mathrm{~h}$. Após este período, uma única colônia foi transferida para um frasco erlenmeyer, contendo $250 \mathrm{ml}$ de meio de cultura YEP líquido, suplementado com os antibióticos, incubados sob agitação a $200 \mathrm{rpm}, 28^{\circ} \mathrm{C}$, por $16 \mathrm{~h}$. A suspensão bacteriana foi centrifugada a $15{ }^{\circ} \mathrm{C}$ e $4800 \mathrm{rpm}$, por $10 \mathrm{~min}$. $\mathrm{O}$ pellet foi resuspendido em meio de cultura MS, na concentração de $10^{9}$ céls $/ \mathrm{ml}$.

Agrobacterium tumefaciens EHA 105 é uma estirpe desarmada derivada da

estirpe de A. tumefaciens A281 (Hood et al., 1993), que é comprovadamente 
supervirulento em citrange 'Carrizo' (Cervera et al., 1998c). O T-DNA contém o gene neomicina fosfotransferase (nptII) controlado pelo promotor e terminador nopalina sintase (NOS), usado como marcador de seleção (NOS pro-NPTII-NOSter) e o gene uidA, controlado pelo promotor e terminador do CaMV35S, como gene repórter (35S pro-GUSINT-35Ster). O intron inserido na região codificadora de proteína do gene $G U S$ bloqueia a expressão do gene em A. tumefaciens.

\subsection{Transformação genética e regeneração de plantas:}

Segmentos de epicótilo $(0,8-1,0 \mathrm{~cm})$ foram incubados na solução bacteriana por 20 minutos. Após a incubação, os explantes foram secos em papel de filtro estéril e incubados em meio de cultura EME (Grosser \& Gmitter Junior, 1990), suplementado com sacarose $\left(25 \mathrm{~g} \mathrm{~L}^{-1}\right)$, BAP $\left(1 \mathrm{mg} \mathrm{L}^{-1}\right)$ e acetoseringona $(100 \mu \mathrm{M})$, no escuro, por um período de 3 dias. Após o co-cultivo, os segmentos foram transferidos para meio de cultura EME suplementado com BAP $\left(1 \mathrm{mg} \mathrm{L}^{-1}\right)$, canamicina $\left(100 \mathrm{mg} \mathrm{L}^{-1}\right)$ e cefotaxime (500 mg L $\mathrm{L}^{-1}$ ) e foram mantidos no escuro, a $27^{\circ} \mathrm{C}$, durante um período pré determinado para cada variedade, citrange 'Carrizo' durante 2 semanas e laranja 'Hamlin' durante 4 semanas. Os explantes foram subcultivados a cada 2 semanas.

Após o desenvolvimento das gemas, as mais vigorosas foram transferidas para meio de cultura EME, suplementado com GA $3\left(1 \mathrm{mg} \mathrm{L}^{-1}\right)$, canamicina $\left(100 \mathrm{mg} \mathrm{L}^{-1}\right) \mathrm{e}$ cefotaxime $\left(500 \mathrm{mg} \mathrm{L}^{-1}\right)$ para alongamento. Para enraizamento, as plantas foram cultivadas em frascos tipo Magenta, contendo meio de cultura MS, com a metade da concentração dos sais e livre de reguladores vegetais ou tiveram seus ápices caulinares microenxertados em plântulas de porta-enxerto cultivadas in vitro.

Para avaliar os fatores que influenciam a frequência da transformação genética, diferentes experimentos foram realizados: 1) segmentos de epicótilo foram co-cultivados sob 4 temperaturas $21,24,27$ ou $30^{\circ} \mathrm{C}$, no escuro, com ou sem acetoseringona (100 $\mu \mathrm{M})$; 2) segmentos de epicótilo foram incubados no escuro ou em fotoperíodo de 16-h após o período de co-cultivo; 3) acetoseringona $(100 \mu \mathrm{M})$ foi adicionada em diferentes etapas do processo de transformação genética (meio de cultura de crescimento da bactéria, meio de cultura para resuspensão do 'pellet' da bactéria e inoculação dos 
explantes ou no meio de cultura de co-cultivo), como descrito na Tabela 1) segmentos de epicótilo foram co-cultivados em meio de cultura com $\mathrm{pH}$ ajustado para 5,2, 5,5 ou 5,8 com ou sem acetoseringona $(100 \mu \mathrm{M}) ; 5)$ segmentos de epicótilo foram co-cultivados em meio de cultura suplementado com auxina $\left(2 \mathrm{mg} \mathrm{L}^{-1}\right.$ de AIA, $1 \mathrm{mg} \mathrm{L}^{-1}$ de 2-iP e 2 $\mathrm{mg} \mathrm{L}^{-1}$ de 2,4-D), como descrito por Ghorbel et al. (2001), com ou sem acetoseringona $(100 \mu \mathrm{M}) ; 6)$ segmentos de epicótilo foram seccionados, para proporcionar maior área de contato entre a bactéria e as células do câmbio vascular, e foram cultivados na posição horizontal.

Tabela 1. Esquema dos tratamentos para o experimento com acetoseringona $(100 \mu \mathrm{M})$ em diferentes etapas do processo de transformação genética em citrus.

\begin{tabular}{cccc}
\hline Tratamentos & $\begin{array}{c}\text { Meio de crescimento } \\
\text { bacteriano }\end{array}$ & $\begin{array}{c}\text { Suspensão } \\
\text { bacteriana }\end{array}$ & $\begin{array}{c}\text { Meio de } \\
\text { co-cultivo }\end{array}$ \\
\hline $\mathrm{A}$ & $+\mathrm{AS}$ & $+\mathrm{AS}$ & $+\mathrm{AS}$ \\
$\mathrm{B}$ & $+\mathrm{AS}$ & $+\mathrm{AS}$ & $-\mathrm{AS}$ \\
$\mathrm{C}$ & $+\mathrm{AS}$ & $-\mathrm{AS}$ & $-\mathrm{AS}$ \\
$\mathrm{D}$ & $-\mathrm{AS}$ & $+\mathrm{AS}$ & $+\mathrm{AS}$ \\
$\mathrm{E}$ & $-\mathrm{AS}$ & $+\mathrm{AS}$ & $-\mathrm{AS}$ \\
$\mathrm{F}$ & $-\mathrm{AS}$ & $-\mathrm{AS}$ & $-\mathrm{AS}$ \\
\hline
\end{tabular}

Após um período de 2 meses de incubação, realizou-se a avaliação quanto ao número de gemas produzidas por explante, em cada tratamento. Após a realização do ensaio histoquímico $G U S$, calculou-se a eficiência de transformação genética definida por Peña et al. (1995b), como sendo o resultado do número de gemas transformadas obtidas em relação ao número de explantes inoculados. Os experimentos foram realizados utilizando o delineamento experimental inteiramente casualizado, sendo que cada tratamento continha de 3-5 repetições, cada repetição contendo de 25-30 explantes, sendo assim, para cada tratamento foram utilizados de 75-150 explantes.

Para análise das prováveis gemas transformadas foi realizado o ensaio histoquímico GUS, baseado na clivagem do substrato 5-bromo-4-cloro-3-indolil- $\beta$-Dglucuronídeo cicloexil amina(X-gluc) pela enzima $\beta$-glucuronidase. O produto desta reação, na presença de oxigênio, forma dímeros, resultando em um precipitado insolúvel, de cor azul (Jefferson, 1987).

Folhas de plântulas regeneradas e segmentos de epicótilo foram incubados em solução X-gluc no escuro, a $37^{\circ} \mathrm{C}$. Esta reação pode levar alguns minutos até 16 horas 
ou mais. Após, o tempo de reação o material é lavado em álcool $70 \%$ e observado em microscópio estereoscópico.

\subsection{Análise estatística}

Os experimentos foram realizados utilizando-se de 3 a 5 repetições, cada repetição contendo 25 ou 30 explantes. O delineamento estatístico foi inteiramente casulalizado. A análise estatística foi realizada utilizando-se o "software" ESTAT, desenvolvido na UNESP, Jaboticabal, SP. Primeiramente foi aplicado um teste de variância e em seguida aplicado o teste Tukey, para comparação das médias. Os dados de eficiência de transformação foram transformados para $(x+0,5)^{1 / 2}$.

\subsection{Análise histológica associada ao teste histoquímico GUS}

Segmentos de epicótilo seccionados após 3 dias de co-cultivo, foram incubados em solução X-gluc, mantidos a $37^{\circ} \mathrm{C}$, durante 24 horas. Após este período foram fixados em solução de Karnowsky por 24 horas e então desidratados em série alcoólica etílica até $70 \%$. A clorofila foi removida com trocas de álcool $70 \%$ até sua completa remoção. Foram realizados cortes a mão livre, que foram observados em microscópio para análise dos pontos de expressão transiente do gene uidA. 


\section{RESULTADOS E DISCUSSÃO}

A obtenção de plantas de Citrus geneticamente modificadas tem sido feita na maioria das vezes utilizando o sistema Agrobacterium tumefaciens (Moore et al., 1992; Kaneyoshi et al., 1994; Peña et al, 1995a; 1995b; 1997; Cervera et al., 1998; Bond \& Roose, 1998). Porém, os protocolos utilizados mostram uma baixa eficiência de transformação. Os fatores que afetam a eficiência de indução dos genes vir e transferência do T-DNA são muitos, e têm sido testados na tentativa de otimizar os protocolos de transformação genética para Citrus.

Os dados apresentados a seguir são representativos das duas variedades estudadas, porém a análise estatística foi realizada separadamente, não sendo o objetivo testar interação entre as duas variedades e sim observar quais as condições ideais para cada uma delas.

\subsection{Fatores relacionados à indução dos genes vir}

Acetoseringona e outros compostos fenólicos estão diretamente ligados ao processo de ativação dos genes da região vir, responsáveis pela transferência do T-DNA para a célula vegetal (Stachel et al., 1985).

Em citrange 'Carrizo' a eficiência de indução de gemas $\mathrm{GUS}^{+}$foi levemente maior quando acrescentou-se acetoseringona ao meio de crescimento da bactéria, porém este aumento não foi significativo estatisticamente, enquanto em laranja doce 'Hamlin' os resultados foram opostos, as maiores taxas de regeneração de plantas transformadas foi obtido quando o meio de cultura para crescimento da bactéria não foi suplementado com acetoseringona (Figura 1). A análise estatística mostra que o tratamento D foi o mais eficiente, porém não difere estatisticamente dos tratamentos $\mathrm{C}$ e $\mathrm{E}$ (Tabela 1). 


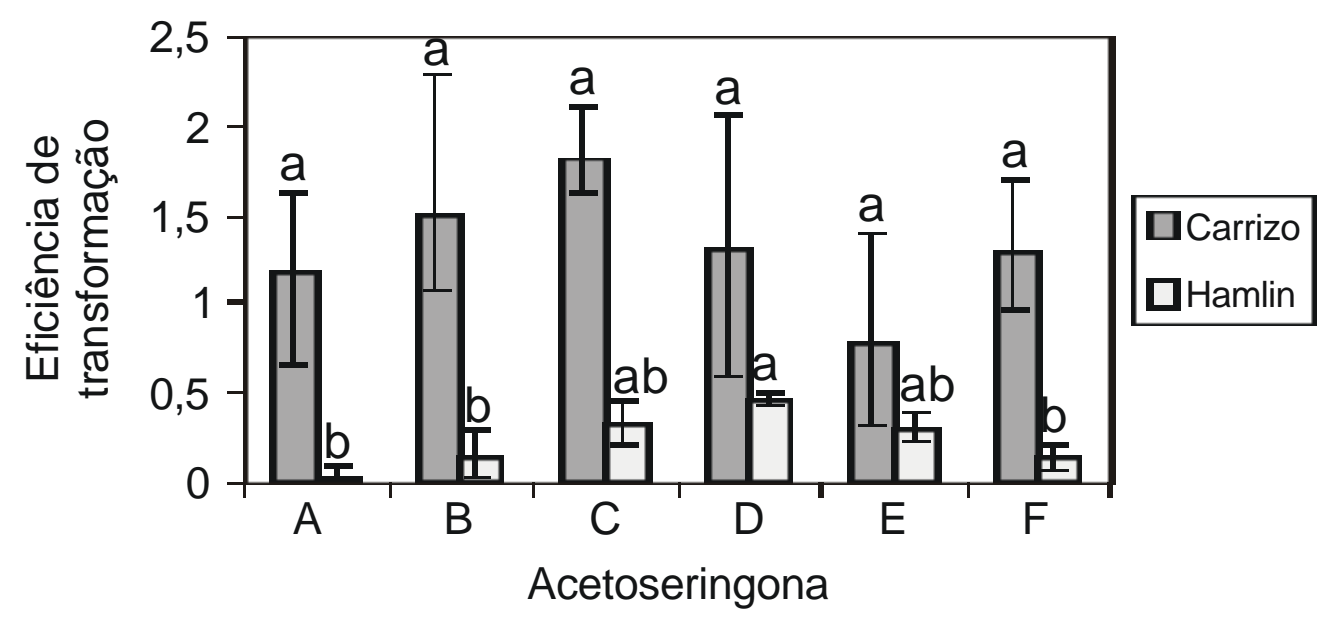

Figura 1- Eficiência de transformação genética em segmentos de epicótilo de laranja doce 'Hamlin' e citrange 'Carrizo' em relação ao uso de acetoseringona em diferentes etapas do processo de transformação genética. Médias correspondentes a 3 repetições, contendo cada uma 30 explantes. Letras iguais não são significativamente diferentes a 0,01 pelo teste Tukey. $C V=7,5$ (Hamlin) e CV=16,8 (Carrizo).

Acetoseringona tem promovido um aumento nos níveis de transformação genética em várias espécies (Sheikholeslam \& Weeks, 1987; Mathews et al., 1990; Godwin et al., 1991; Jacq et al., 1993; James et al., 1993; Confalonieri et al., 1995). Em citros, a acetoseringona já vem sendo utilizada em protocolos de transformação de laranja doce (Bond \& Rose, 1998), citrange 'Carrizo' (Cervera et al., 1998b) e grapefruit Rio Red (Citrus paradisi Macf.), onde acetoseringona foi adicionado em todas as etapas do processo de transformação genética (Yang et al., 2000). Kaneyoshi et al. (1994) utilizaram acetoseringona na suspensão bacteriana e no meio de co-cultivo em Poncirus trifoliata obtendo uma eficiência de transformação de 55,4\%.

Porém, nem sempre a adição de acetoseringona proporciona um incremento na eficiência de regeneração de gemas transformadas. Em cenoura (Pawlicki et al., 1992), tabaco e tomate (Fillati et al., 1987) esse aumento não foi significativo, indicando que estas espécies possuem quantidades suficientes de compostos fenólicos para ativar os genes de virulência.

Além de compostos fenólicos, outro fator relacionado a transferência do TDNA, é a temperatura de incubação durante o período de co-cultivo, sugerindo fortemente que a termo-sensibilidade no desenvolvimento da 'galha da coroa' reflete a 
dependência da temperatura para transferência do T-DNA (Dillen et al., 1997).

O efeito da temperatura no co-cultivo foi estudado em Nicotiana tabacum e Phaseolus acutifolius, onde as melhores temperaturas ficaram entre 19 e $22{ }^{\circ} \mathrm{C}$. Estes resultados vão de encontro àqueles encontrados por Riker (1926), onde a formação de tumor em planta foi obtido à temperatura de $22^{\circ} \mathrm{C}$.

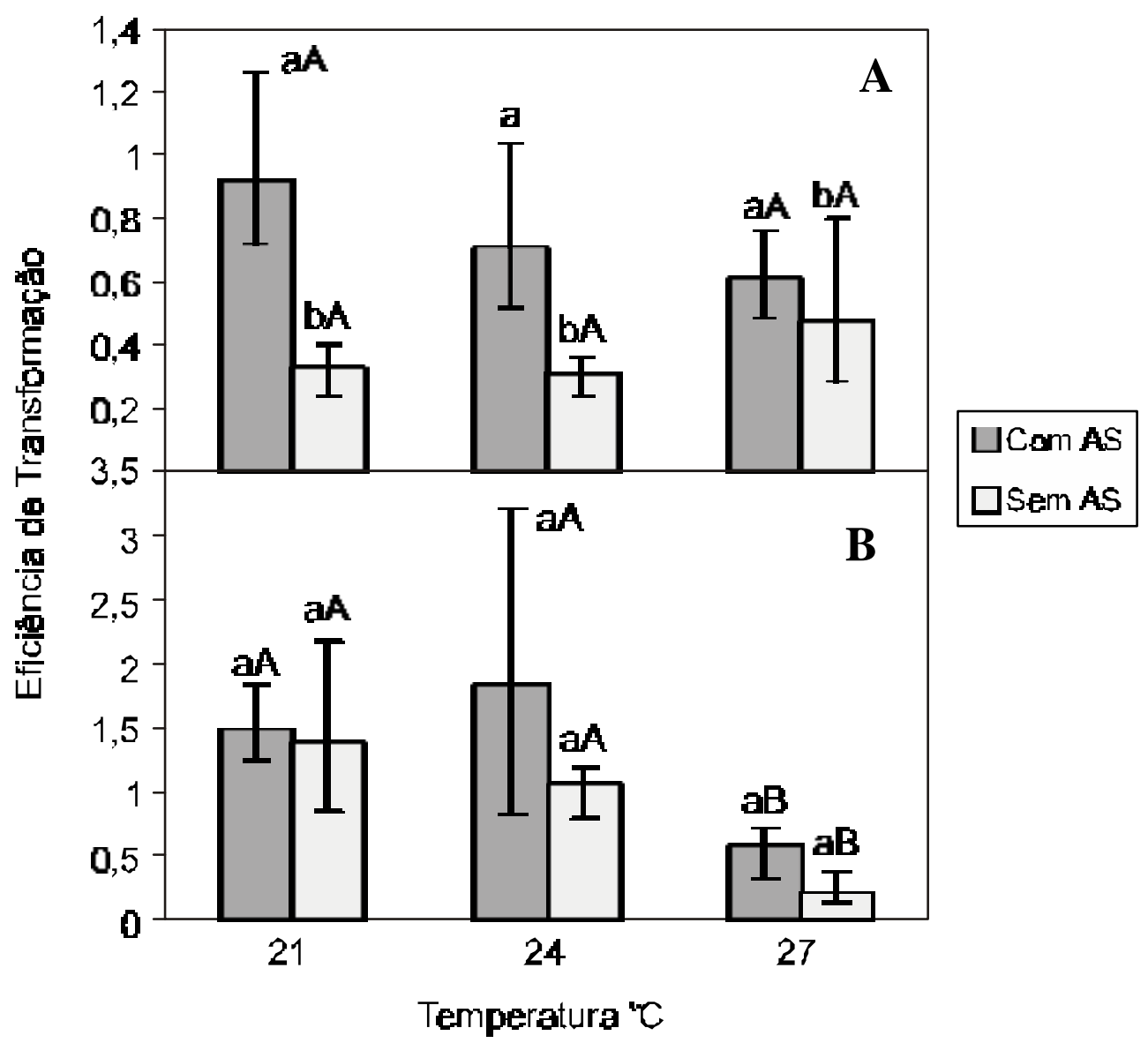

Figura 2- Eficiência de transformação genética de segmentos de epicótilos de laranja doce 'Hamlin' (A) e citrange 'Carrizo' (B) sob diferentes temperaturas de co-cultivo associada a presença ou ausência de acetoseringona ao meio de cultura. Médias correspondentes a 3 repetições, contendo cada uma 25 explantes. Letras minúsculas representam o fator acetoseringona e letras maiúsculas representam o fator temperatura, sendo que letras iguais não são significativamente diferentes a 0,05 pelo teste Tukey. $\quad C V=9,6$ (Hamlin) e $C V=16,8$ (Carrizo) 
Em citrange 'Carrizo' o uso de temperaturas abaixo de $27{ }^{\circ} \mathrm{C}$ aumentou a eficiência de transformação genética, porém não foi observada nenhuma interação entre acetoseringona e temperatura (Figura 2). Para laranja doce 'Hamlin' a utilização de temperaturas inferiores a $27{ }^{\circ} \mathrm{C}$ proporcionou um incremento na eficiência de transformação, não havendo diferença estatística entre as temperaturas de 21 e $24{ }^{\circ} \mathrm{C}$. A temperatura escolhida como sendo a mais adequada para realização dos experimentos foi $24{ }^{\circ} \mathrm{C}$. Temperaturas mais baixas $\left(22^{\circ} \mathrm{C}\right)$ durante o co-cultivo foram utilizadas na transformação genética de pomelo resultando em altas taxas de transformação genética (Yang et al., 2000).

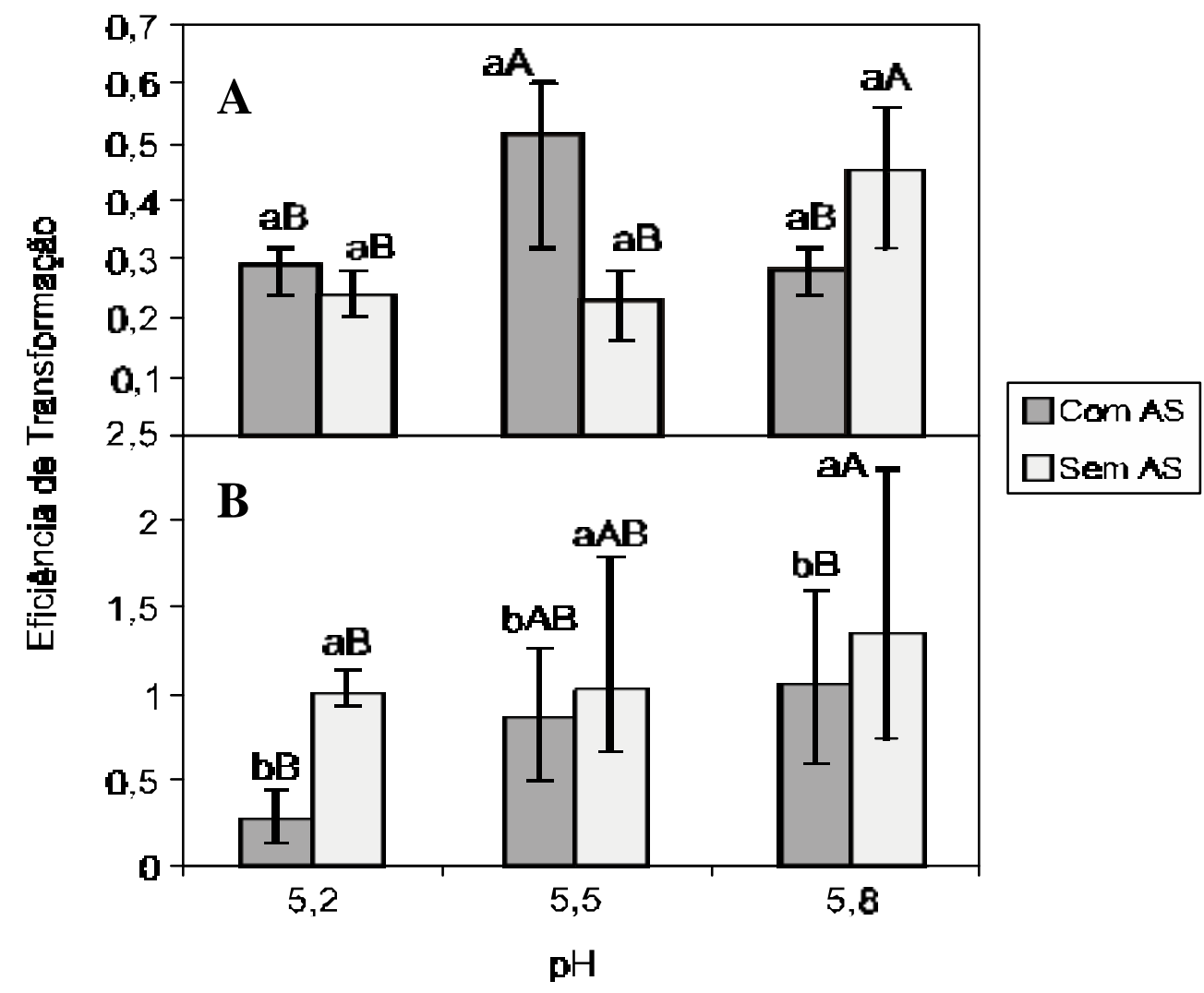

Figura 3- Eficiência de transformação genética de segmentos de epicótilo de laranja doce 'Hamlin' (A) e citrange 'Carrizo' (B) sob diferentes pH no meio de cultura de co-cultivo associada a presença ou ausência de acetoseringona. Médias correspondentes a 3 repertições, contendo 25 explantes. Letras minúsculas representam o fator acetoseringona e letras maiúsculas o $\mathrm{pH}$ do meio de cocultivo, sendo que letras iguais não são significativamente diferentes a 0,01 pelo teste Tukey. CV=5,3 (Hamlin) e CV=13,82 (Carrizo). 
Sabe-se que a acetoseringona ativa os genes vir a pH baixo $(5,0-5,5)$ e assim dá início ao processo de transferência do T-DNA (Stackel et al., 1985; 1986). A importância do $\mathrm{pH}$ na presença de um agente indutor de virulência tem sido relatada em diversos trabalhos. Godwin et al. (1991) e Holford et al. (1992) obtiveram um incremento na freqüência de transformação de Antirrhinum majus quando o $\mathrm{pH}$ foi abaixado, porém isto ocorreu somente na presença de acetoseringona. $\mathrm{O}$ mesmo ocorre com algumas espécies de orquídeas (Belarmino \& Mii, 2000) e em Brassica campestris L. (Zhang et al.,2000), onde foi utilizado pH 5,4 e 5,2 com a adição de acetoseringona ao meio cultura para o co-cultivo.

Os resultados em laranja doce 'Hamlin' confirmam estes relatos. A análise estatística mostra uma interação entre os fatores pH e acetoseringona, obtendo-se uma maior eficiência de transformação genética quando a acetoseringona é adicionada ao meio de cultura de co-cultivo com $\mathrm{pH}$ mais baixo (5,2 e 5,5), entretanto quando o $\mathrm{pH}$ foi ajustado para 5,8 a adição de acetoseringona não aumentou a eficiência de transformação (Figura 3). Em citrange 'Carrizo' este efeito não foi observado, a adição de acetoseringona não mostrou um efeito significativo sobre a eficiência de transformação.

Trabalhos utilizando 'feeder plates' ou cultura de células em suspensão de tomate, que são ricos em auxina, têm sido utilizados com sucesso em sistemas de transformação genética via Agrobacterium em citros (Peña et al., 1997; Cervera et al., 1998; Domíguez et al., 2000). Cervera et al. (1998) mencionam a importância das auxinas na indução de células competentes para transformação em citrange 'Carrizo', possivelmente devido ao aumento da taxa de desdiferenciação e conseqüente indução de divisão e diferenciação celular (Cervera et al., 1998).

Os resultados obtidos com a suplementação do meio de cultura de co-cultivo com auxina (AIA, 2,4-D e 2-iP-Ghorbel et al., 2001) não mostraram aumento na eficiência da transformação genética, porém a adição de acetoseringona somente no cocultivo tem proporcionado melhores resultados tanto para laranja doce como para citrange ‘Carrizo'(Figura 4). 


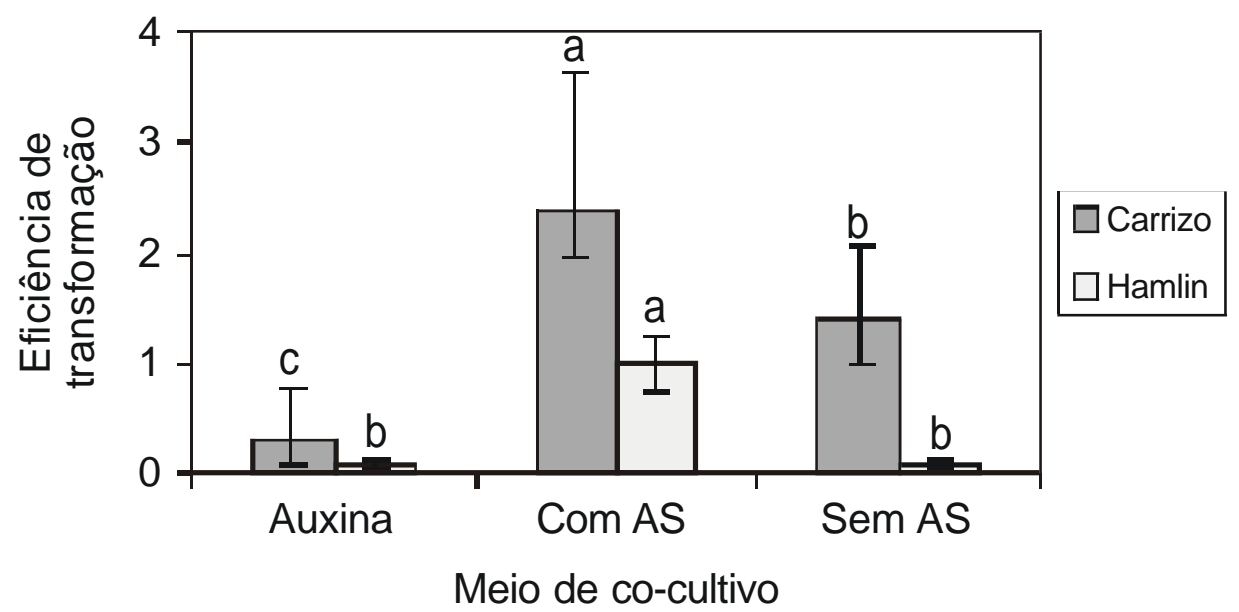

Figura 4 Eficiência de transformação genética de segmento de epicótilo de laranja doce 'Hamlin' e citrange 'Carrizo' em meio de cultura de co-cultivo contendo auxina e acetoseringona. Médias correspondentes a 5 repetições, contendo cada uma 25 explantes. Letras iguais não são sinificativamente diferentes a 0,01 pelo teste Tukey. $\mathrm{CV}=6,27$ (Hamlin) e $\mathrm{CV}=13,1$ (Carrizo).

Em citrus o efeito da acetoseringona adicionada ao meio de co-cultivo já foi relatada em vários trabalhos. Temperaturas mais baixas e o efeito sinergístico entre $\mathrm{pH}$ e acetoseringona parecem ter grande influência sobre a ativação dos genes vir e a consequente transferência do T-DNA para a célula vegetal.

\subsection{Fatores relacionados ao tipo de explante e condições de incubação pós co-cultivo}

A organogênese in vitro em explantes de citrus ocorre de forma direta (Figura 6b), sem a formação de calos quando estes explantes são incubados sob fotoperíodo de 16-h, ou de forma indireta (Figura 6a, 6c), quando são incubados em ausência de luz, havendo neste caso, a formação de calos e a regeneração de gemas adventícias a partir destas células.

Em experimentos de transformação genética de citros a incubação dos explantes no escuro após o co-cultivo tem proporcionado um aumento na eficiência de transformação. Peña et al. (1995a; 1995b) obtiveram aumento na eficiência de transformação de citrange 'Carrizo' e laranja doce, quando utilizaram um período de 8 semanas de incubação no escuro antes de transferir para fotoperíodo de 16-h. Porém longos períodos de exposição ao escuro produziram gemas estioladas que mostraram abscisão, embranquecimento e morte, mais recentemente este tempo de incubação foi 
reduzido e adaptado de acordo com o genótipo (Peña et al., 1996). Durán-Vila et al. (1992) também obtiveram resultados semelhantes com laranja doce. Porém, existem trabalhos resultando em aumento na freqüência de regeneração de plantas de citros transformadas quando os segmentos foram transferidos diretamente para a luz após o cocultivo (Kaneyoshi et al.,1994).

Explantes expostos a fotoperíodo de 16 - $\mathrm{h}$ regeneram maior percentagem de gemas, mas também apresentam maior número de escapes, com pouca ou nenhuma formação de calos. O cultivo dos explantes no escuro favorece a formação de calos e desta forma aumentam o número de gemas transformadas que são $\mathrm{GUS}^{+}$, e ao mesmo tempo evitando a regeneração de escapes que poderiam ser estimuladas pela exposição dos explantes diretamente na luz (Cervera et al., 1998).

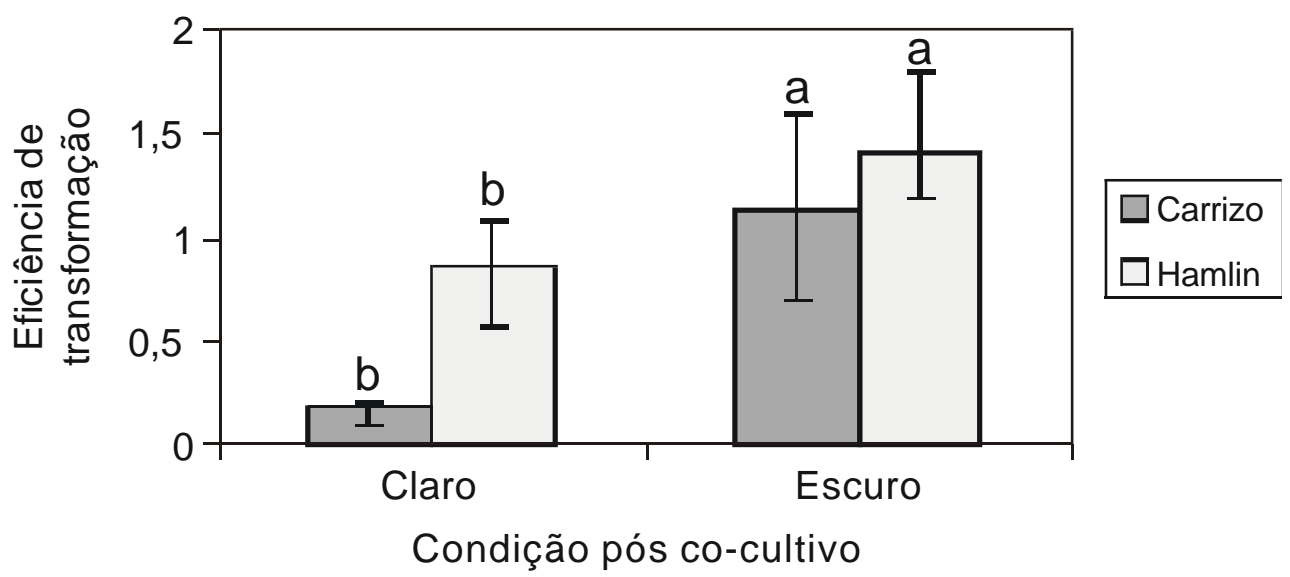

Figura 5 Eficiência de transformação genética em segmento de epicótilo de citrange 'Carrizo' e laranja doce 'Hamlin' cultivados sob fotoperíodo de 16-h luz ou na ausência de luz após o período de co-cultivo. Médias corrspondentes a 5 repetições, contendo cada uma 25 explantes. Letras diferentes representam diferença estatística a 0,01 pelo teste Tukey. CV=7,18 (Hamlin) e CV=8,99 (Carrizo)

Quando estes explantes foram mantidos no escuro durante um tempo maior as gemas estiolaram, se tornaram aclorofiladas e morreram assim como relatado por Peña et al. (1997). Os resultados obtidos neste trabalho confirmam relatos anteriores onde os explantes incubados no escuro apresentaram maior número de gemas transformadas. Após exposição de 4 semanas no escuro, segmentos de laranja doce 'Hamlin' apresentaram uma eficiência de transformação de aproximadamente 2 vezes do que foi 
obtido quando se transferiu os segmentos diretamente para a luz, para segmentos de citrange 'Carrizo' este número foi 10 vezes maior durante um tempo de duas semanas no escuro (Figura 5). A partir de observações realizadas, explantes de citrange 'Carrizo' foram incubados por 2 semanas e os de laranja 'Hamlin' por 4 semanas, a $27^{\circ} \mathrm{C}$. Este período foi suficiente para início de formação de gemas.

Trabalhos de histologia realizados em culturas organogênicas com objetivo de visualizar a origem de gemas adventícias em variedades cítricas indicam que a origem se dá a partir de células cambiais (Almeida et al., 2002; García-Luis et al., 1999).

Em laranja doce, a organogênese direta inicia-se no câmbio com o aumento do número de camadas de células seguido pela formação de áreas meristemáticas a partir das quais surgem as gemas (Almeida et al., 2002). Segundo Mukhopadhayay et al. (1992) a origem endógena das gemas pode reduzir a eficiência de transformação genética devido a dificuldade de contato entre a bactéria e as células meristemáticas. Isto poderia explicar a menor eficiência de regeneração de células transformadas em variedades de laranja doce.

García-Luis et al. (1999), estudando a regeneração de segmentos de epicótilo de citrange 'Troyer' nas mesmas condições de cultivo utilizadas por Almeida et al. (2002) para laranja doce. Porém, segundo os autores, explantes cultivados na posição horizontal apresentam proliferação de calos a partir do câmbio, sendo indireta a origem das gemas.

Partindo-se do princípio de que as origem das gemas é endógena em culturas de variedades cítricas, foi realizado um experimento variando o tipo de corte do explante, seccionando-o longitudinalmente a fim de expor uma maior superfície da região cambial aumentando assim o contato entre o tecido cambial e a bactéria. Alguns segmentos seccionados de citrange 'Carrizo' foram coletados após o período de cocultivo e incubados em solução X-gluc para realização de cortes histológicos. A análise dos cortes mostra a expressão do gene uidA (gus) em células parênquimáticas das últimas camadas do córtex, em todo o floema e na região cambial (Figura 6f). 

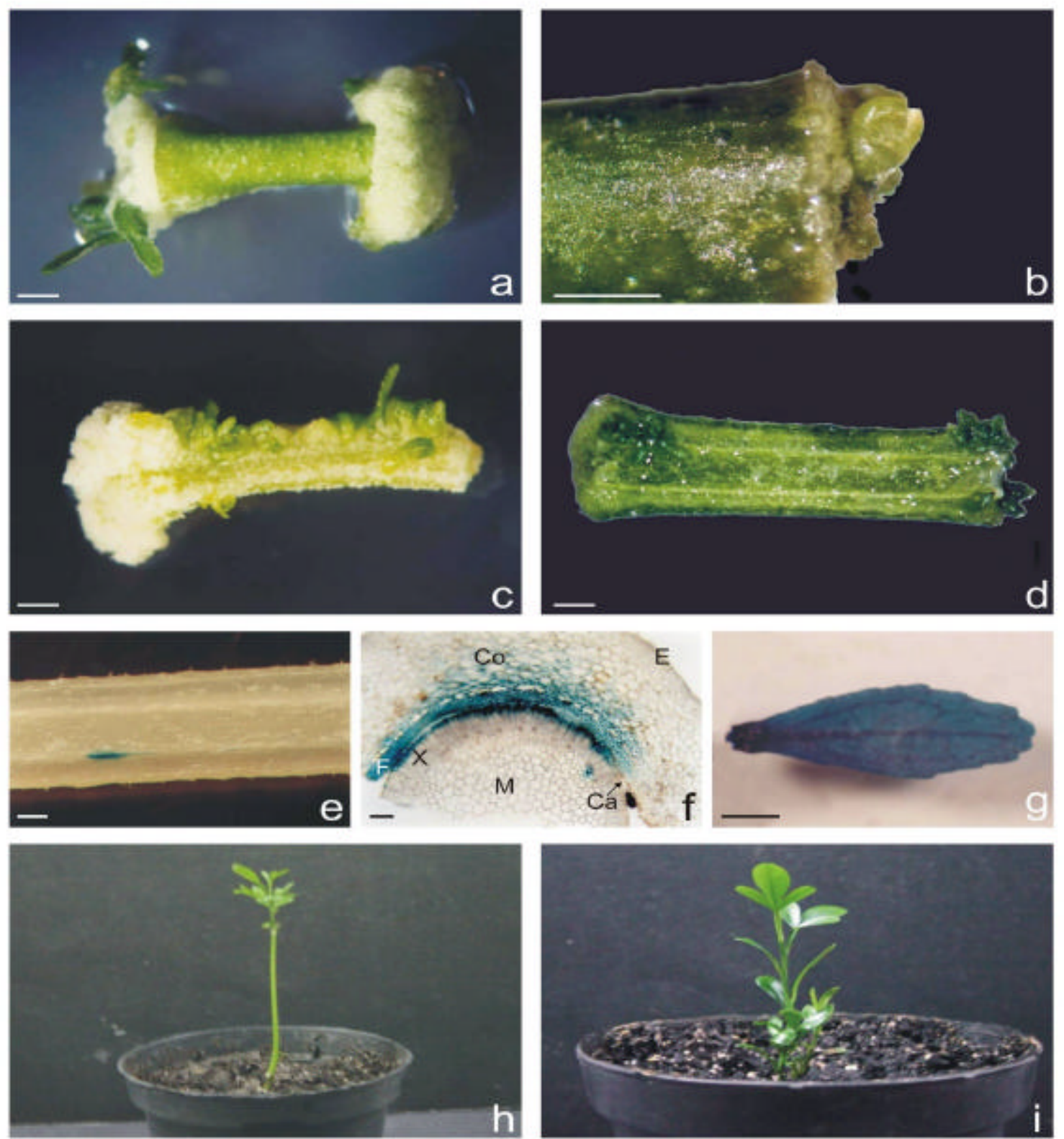

Figura 6 - a) organogênese indireta em segmentos de epicótilo de citrange 'Carrizo'; b) organogênese direta em segmentos de epicótilo de citrange 'Carrizo'; c) organogênese indireta em segmento de epicótilo de citrange 'Carrizo' seccionado longitudinalmente; d) organogênese direta em segmento de epicótilo de citrange 'Carrizo' seccionado longitudinalmente; e) segmento de epicótilo seccionado longitudinalmente, expressando o gene uidA após 3 dias de co-cultivo (teste histoquímico GUS); f) Corte transversal de um segmento de epicótilo de citrange 'Carrizo' seccionado longitunalmente após reação em X-gluc. Ca, câmbio; Co, córtex; $\mathrm{F}$, floema; $\mathrm{X}$, xilema; $\mathrm{M}$, medula; $\mathrm{g}$ ) folha de citrange 'Carrizo' expressando $o$ gene uidA após teste histoquímico GUS; h) ápice meristemático de laranja doce microenxertado em citrange 'Carrizo', crescendo em substrato na casa-devegetação; i) planta transformada de citrange 'Carrizo' enraizada in vitro, crescendo em substrato na casa-de-vegetação. (barras $=1 \mathrm{~mm}$ (a-e, g), barra $=100 \mu \mathrm{m}$ (f)). 
Embora, a superfície exposta à bactéria tenha sido maior no corte longitudinal do explante e a reação positiva do ensaio histoquímico gus tenha coincidido com a área de regeneração das gemas, não houve uma diferença significativa no número de gemas transformadas obtidas com este tipo de secção quando comparado ao explante inteiro (Figura 7). Isto pode ser afirmado porque o número de gemas formadas no explante seccionado longitudinalmente e cultivado com Agrobacterium foi muito inferior comparando-se com a regeneração de gemas a partir de explantes não cultivados com a bactéria. Talvez o crescimento da Agrobacterium ao longo da superfície do explante não tenha sido eficientemente controlado pelo antibiótico, podendo ter interferido na capacidade organogênica do tecido, o explante não seccionado foi utilizado nos demais experimentos realizados.

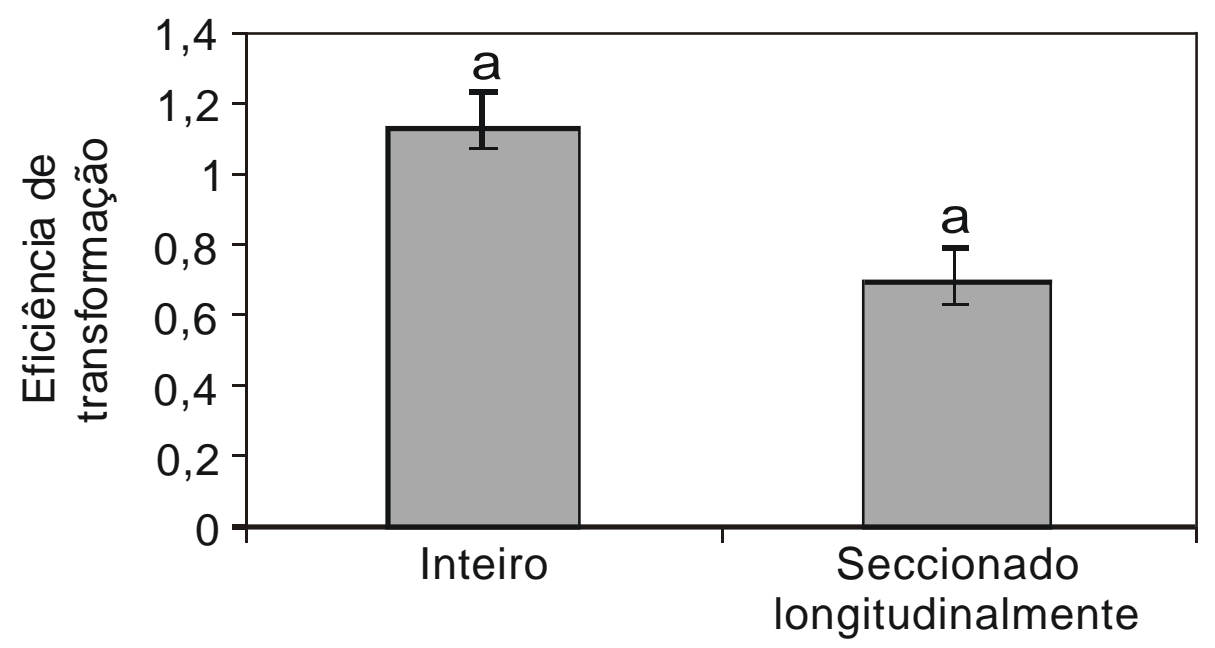

Tipo de explante

Figura 7- Eficiência de transformação genética de segmento de epicótilo citrange 'Carrizo' inteiro ou seccionado longirudinalmente. Médias correspondentes a 4 repetições, contendo cada uma 25 segmentos. Letras iguais não são significativamente diferentes a 0,01 pelo teste Tukey. $\mathrm{CV}=10,01$ (Carrizo)

Outras tentativas foram realizadas buscando o tipo e posição de cultivo do explante para citros, segmentos internodais ou de epicótilo foram cultivados na posição vertical, com apenas uma gota de suspensão sobre o corte (Moore et al., 1992; Peña et al., 1995a), mas o explante não seccionado cultivado na posição horizontal tem mostrado 
melhores resultados (Kaneyoshi et al., 1994; Peña et al., 19955b; 1997; Cervera et al., 1998; Bond \& Roose, 1998; Luth \& Moore, 1999).

Segmentos internodais retirados de plantas cultivadas em casa-de-vegetação apresentam problemas de contaminação por bactéria endógena, e a freqüência de transformação é mais baixa quando comparada a segmentos de epicótilo retirados de plântulas germinadas in vitro.

A baixa eficiência em transformação de citrus é devido ao crescimento de gemas não transformadas e a dificuldade de enraizamento de gemas transgênicas (Peña et al., 1995a; Gutiérrez-E. et al., 1997; Yang et al., 2000). A média de escapes foi de $16,4 \%$ e 17,8\% para laranja 'Hamlin' e citrange 'Carrizo' respectivamente, mostrando que nos experimentos avaliados o efeito seletivo da canamicina foi eficiente contrastando com números altos de regeneração de escapes (Moore et al., 1992). Alguns autores relatam altos índices de escapes justificados por 1) uma proteção que as células transformadas exercem sobre as não transformadas; 2) atividade endógena não específica do gene nptII em células transformadas; 3) ou por contaminação de Agrobacterium (Moore et al., 1992; Peña et al., 1995b; Gutiérrez-E. et al.,1997).

Tabela 2. Relação das médias de eficiência de transformação genética e de escapes para experimentos realizados com segmentos de epicótilo de citrange 'Carrizo' e laranja doce 'Hamlin'.

\begin{tabular}{ccccc}
\hline Fatores estudados & $\begin{array}{c}\text { Eficiência de transform. } \\
\text { 'Hamlin' (\%) }\end{array}$ & $\begin{array}{c}\text { \% de escapes } \\
\text { 'Hamlin' }\end{array}$ & $\begin{array}{c}\text { Eficiência de transform. } \\
\text { 'Carrizo' (\%) }\end{array}$ & $\begin{array}{c}\text { \% de escapes } \\
\text { 'Carrizo' }\end{array}$ \\
\hline pH & 27,3 & 1,9 & 107 & 14,4 \\
temperatura & 47,2 & 12,4 & 90,2 & 12 \\
acetoseringona & 19,6 & 11,3 & 118 & 9,5 \\
auxina/aceto & 38 & 20 & 163 & 9,3 \\
cortes & 12 & 33 & 91 & 29 \\
condição pós co- & 114,5 & 20 & 66,5 & 32,6 \\
cultivo & & & & \\
\hline
\end{tabular}

O problema de enraizamento das plantas regeneradas foi contornado realizando-se microenxertia de ápices caulinares em plantas porta-enxerto germinadas in vitro (Figura 6h) ou cultivando as plântulas regeneradas em meio MS contendo a metade 
da concentração dos sais, sem adição de reguladores vegetais e mantendo-as em fotoperíodo de 16-h por 40-60 dias até o aparecimento das raízes (Figura 6i). Estas plantas tem sido aclimatizadas com relativa facilidade e algumas já estão sendo cultivadas em condições de casa-de-vegetação.

No geral pode-se afirmar que a eficiência de transformação nestes experimentos foi satisfatória, sendo que em alguns experimentos este valor foi de $100 \%$ ou superior, entendendo-se que para 25 segmentos inoculados por repetição, uma ou mais gemas transformadas foram regeneradas utilizando-se este protocolo.

Em síntese, pode-se dizer que temperatura de $24{ }^{\circ} \mathrm{C}$ no co-cultivo, meio de cocultivo com pH ajustado para 5,8 com ou sem adição de acetoseringona, com explante transversal cultivado na posição horizontal e incubados no escuro durante 2 semanas após o período de co-cultivo são condições ideais para obtenção de plantas de citrange 'Carrizo' transformadas. Para laranja 'Hamlin', temperaturas de 21 ou $24{ }^{\circ} \mathrm{C}$ durante o co-cultivo, porém a adição de acetoseringona ao meio parece ter maior efeito quando o $\mathrm{pH}$ é mais baixo do que 5,8. Os experimentos de $\mathrm{pH}$ foram realizados à temperatura de $24{ }^{\circ} \mathrm{C}$ e os experimentos de temperatura foram realizados em meio de cultura com $\mathrm{pH}$ ajustado para 5,8, mas a acetoseringona foi adicionada ao meio de co-cultivo em ambos experimentos. O tempo de permanência no escuro após o período de co-cultivo foi de 4 semanas, utilizando o mesmo tipo de explante e posição de cultivo. 


\section{CONCLUSÕES}

- a transformação genética via Agrobacterium tumefaciens em citros é genótipo dependente e a estirpe utilizada, EHA 105, mostrou uma maior afinidade para transformar células da variedade citrange 'Carrizo';

- $\mathrm{pH}$, temperatura e acetoseringona afetam a eficiência de transformação em citrange 'Carrizo' e laranja 'Hamlin';

- existe interferência da quantidade de luz na incubação dos explantes após o período de co-cultivo na eficiência de transformação;

- uma maior exposição das células próximas à região do câmbio, no seccionamento longitudinal do explante, aumentou a freqüência de organogênese, mas o mesmo não ocorreu com a eficiência de transformação. 


\section{REFERÊNCIAS BIBLIOGRÁFICAS}

ALMEIDA, W.A.B.; MOURÃO FILHO, F.A.A.; MENDES, B.M.J.; RODRIGUEZ, A.P.M. Histological characterization of in vitro adventitious organogenesis in Citrus sinensis L. Osbeck. International Journal of Plant Sciences, 2002. /No prelo/.

ALT-MOERBE, J.; NEDDERMANN， P.; VON LINTIG, J.; WEILER, E.W.; SCHROEDER, J. Temperature-sensitive step in Ti plasmid vir-region induction and correlation with cytokinin secretion by Agrobacteria. Molecular and General Genetics, v.213, p.1-8, 1988.

BARLASS, M.; SKENE, K.G.M. In vitro plantlet formation from citrus species and hybrids. Scientia Horticulturae, v.17, p.333-341, 1982.

BELARMINO, M.M.; MII, M. Agrobacterium-mediated genetic transformation of a phalaenopsis orchid. Plant Cell Reports, v.19, p. 435-442, 2000.

BHAT, S.R.; CHITRALEKHA, P.; CHANDEL, K.P.S. Regeneration of plants from long term root culture of lime, Citrus aurantifolia (Cristm.) Swing. Plant Cell, Tissue and Organ Culture, v.29, p.19-25, 1992.

BOND, J.E.; ROOSE, M.L. Agrobacterium-mediated transformation of the commercially important citrus cultivar Washington navel orange. Plant Cell Reports, v.18, p.229-234, 1998. 
BURGER, D.W.; HACKETT, W.P. The isolation, culture and division of protoplasts from citrus cotyledons. Physiologia Plantarum, v.56, p.324-328, 1982.

CABASSON, C.; ALVARD, D.; DAMBIER, D.; OLliRAULT, P.; TEISSON, C. Improvement of citrus somatic embryo development by temporary immersion. Plant Cell, Tissue and Organ Culture, v.50, p.33-37, 1997.

CARNEIRO, V.T.C.; CONROI, T.; BARROS, L.M.G.; MATSUMOTO, K. Protoplastos: cultura e aplicações. In: TORRES, A.C.; CALDAS, L.S.; BUSO, J.A. (Ed) Cultura de tecidos e transformação genética de plantas, Brasília: EMBRAPA; SPI; CNPH, 1998. v.1, p.423-458.

CERVERA, M.; LÓPEZ, M.M.; NAVARRO, L.; PEÑA, L. Virulence and supervirulence de Agrobacterium tumefaciens in woody fruit plants. Physiological and Molecular Plant Pathology, v.52, p 67-78, 1998c.

CERVERA, M.; ORTEGA, C.; NAVARRO, A.; NAVARRO, L.; PEÑA, L. Generation of transgenic citrus plants with the tolerance-to-salinity gene HAL2 from yeast. Journal of Horticultural Science \& Biotechnology, v.75, p.26-30, 2000.

CERVERA, M.; PINA, J.A.; JUÁREZ, J.; NAVARRO, L.; PEÑA, L. Agrobacteriummediated transformation of citrange: factors affecting transformation and regeneration. Plant Cell Reports, v.18, p.271-278, 1998b.

CERVERA, M.; JUÁREZ, J.; NAVARRO, A.; PINA, J.A.; DURÁN-VILA, N.; NAVARRO, L.; PEÑA, L. Genetic transformation and regeneration of mature tissues of woody fruit plants bypassing the juvenile stage. Transgenic Research, v.7, p.5159, 1998a. 
CHATURVEDI, H.C.; MITRA, G.C. Clonal propagation of citrus from somatic callus culture. HortScience, v.9, p 118-120, 1974.

CLARE, B.G.; McCLURE, N.C. Agrobacterium. In: SINGH, U.S.; SINGH, R.P.; KOHMOTO, K. (Ed.). Pathogenesis and host specificity in plant diseases. Histopathological, biochemical, genetic amd molecular bases. London: Pergamon, 1995. v.1: p.221-236.

CONFALONIERI, M.; BALESTRAZZI, A.; BISOFFI, S.; CELLA, R. Factors affecting Agrobacterium tumefaciens-mediated transformation in several black poplar clones. Plant Cell, Tissue and Organ Culture, v 43, p.215-222, 1995.

DILlEN, W.; De CLERCQ, J.; KAPILA, J.; ZAMBRE, M.; VAN MONTAGU, M.; ANGENON, G. The effect of temperature on Agrobacterium tumefaciens-mediated gene transfer to plants. The Plant Journal, v.12, p.1459-1463, 1997.

DESSAUX, Y.; PETIT, A.; TEMPÉ, J. Chemistry and biochemistry of opines, chemical mediators of parasitism. Phytochemistry, v.34, p.31-38, 1993.

DIXON, R.A. Isolation and maintence of callus and cell suspension cultures. In: DIXON, R.A.(Ed.) Plant cell culture: a pratical approach. Oxford:IRL Press, 1985. p. 1-20.

DOMÍNGUES, A.; GUERRI, J.; CAMBRA, M.; NAVARRO, L.; MORENO, P.; PEÑA, L. Efficient production of transgenic citrus plants expressing the coat protein gene of citrus tristeza virus. Plant Cell Reports, v.19, p.427-433, 2000.

DURÁN-VILA, N.; ORTEGA, V.; NAVARRO, L. Morphogenesis and tissue culture of three citrus species. Plant Cell Tissue and Organ Culture, v.16, p.123-133, 1989. 
DURÁN-VILA, N.; GOGORCENA, Y.; ORTEGA, V.; ORTIZ, J.; NAVARRO, L. Morphogenesis and tissue culture of sweet orange (Citrus sinensis (L.) Osbeck): Effect of temperature and photosynthetic radiation. Plant Cell Tissue and Organ Culture, v.29, p.11-18, 1992.

EDRISS, M.H.; BURGER, D.W. In vitro propagation of Troyer citrange from epicotyl segments. Scientia Horticulturae, v.23, p.159-162, 1984.

FAO. FAOSTAT-agriculture data. http://www.fao.org (16 mar. 2002).

FILLATI, J.J.; KISER, J.; ROSE, R.; COMAI, L. Efficient transfer of a glyphosate tolerance gene into tomato using a binary Agrobacterium tumefaciens vector. Biotechnology, v.5, p.726-730, 1987.

FLEMING, G.H.; OLIVARES-FUSTER, O.; FATTA DEL-BOSCO, S.; GROSSER, J.W. An alternative method for the genetic transformation of sweet orange. In vitro Cellular Development Biology. v.36, p.450-455, 2000.

FNP CONSULTORIA \& COMÉRCIO. AGRIANUAL 2002: anuário da agricultura brasileira. São Paulo, 2002. 536p.

GARCÍA-LUIS, A.; BORDÓN, Y.; MOREIRA-DIAS, J.M.; MOLINA, R.V.; GUARDIOLA, J.L. Explant orientation and polarity determine the morphogenic response of epicotyl segments of Troyer citrange. Annals of Botany, v.84, p.715723, 1999.

GHORBEL, R.; NAVARRO, L.; DURAN-VILA, N. Morphogenesis and regeneration of whole plants of grapefruit (Citrus paradisi), sour orange (C. aurantium) and alemow (C. macrophylla). Journal of Horticultural Science \& Biotechnology, v.73, p.323-327, 1998. 
GHORBEL, R.; JUÁREZ, J.; NAVARRO, L.; PEÑA, L. Green fluorescent protein as a screenable marker to increase the efficiency of generating transgenic woody fruit plants. Theoretical Applied Genetics, v.99, p.350-358, 1999.

GHORBEL, R.; LA-MALFA, S.; LÓPEZ, M.M.; PETIT, A.; NAVARRO, L.; PEÑA, L. Additional copies of virG pTiBo542 provide a super-transformation ability to Agrobacterium tumefaciens in citrus. Physiological and Molecular Plant Pathology, v. 58, p.103-110, 2001.

GMITTER JUNIOR, F. G.; GROSSER, J.W.; MOORE, G.A. Citrus. In: HAMMERSCHLAG, F.A.; LITZ, R.E. (Ed.). Biotechnology of perennial fruit crops. Wellingford: CAB International, 1992. p.335-369.

GODWIN, I.; TODD, G.; FORD-LLOYD, B.V.; NEWBURY, H.J. The effects of acetosyringone and $\mathrm{pH}$ in Agrobacterium-mediated transformation vary according to plant species. Plant Cell Reports, v. 9, p. 671-675, 1991.

GOH, C.J.; SIM, G.E.; MORALES, C.L.; LOH, C.S. Plantlet regeneration through different morphogenic pathways in pommelo tissue culture. Plant Cell, Tissue and Organ Culture, v.43, p.301-303, 1995.

GROSSER, J.M.; GMITTER JUNIOR, F.G. Protoplast fusion and citrus improvement. Plant Breeding Reviews, v.8, p.339-374, 1990.

GROSSER, J.W.; GMITTER JUNIOR, F.; CHANDLER, J.L. Intergeneric somatic hybrid plants of Citrus sinensis cv. Hamlin and Poncirus trifoliata cv. Flying Dragon. Plant Cell Reports, v.7, p.5-8, 1988a. 
GROSSER, J.W.; GMITTER JUNIOR, F.; CHANDLER, J.L. Intergeneric somatic hybrid plants sexually incompatible woody species: Citrus sinensis and Severinia disticha. Plant Cell Reports, v.75, p.397-401, 1988b.

GROSSER, J.W.; OLLITRAULT, P.; OLIVARES-FUSTER, O. Somatic hybridization in citrus: an effective tool to facilitate variety improvement. In Vitro Cellular Developmental Biology-Plant, v.36, p. 434-449, 2000.

GROSSER, J.M.; JIANG, J.; GMITTER JUNIOR, F.G.; CASTLE, W.S.; CHANDLER, J.L. somatic hybridization: a new approach to citrus rootstock improvement. Fruits, v.53, p.331-334, 1998b.

GROSSER, J.M.; JIANG, J.; MOURÃO FILHO, F.A.A.; LOUZADA, E.S; BAERGEN, K.; CHANDLER, J.L.; GMITTER JUNIOR, F.G. Somatic hybridization, an integral component of citrus cultivar improvement: I Scion Improvement. HortScience, v.33, p.1057-1059, 1998a.

GROSSER, J.M.; MOURÃO FILHO, F.A.A.; GMITTER JUNIOR, F.G.; LOUZADA, E.S.; RANG, J.; BAERGEN, K.; QUIROS, A.; CABASSON, C.; SCHELL, J.L.; CHANDLER, J.L. Allotetraploid hybrids between Citrus and seven related genera produced by somatic hybridization. Theoretical and Applied Genetics, v.92, p.557$582,1996$.

GUTIÉRREZ-E, M.A.; LUTH, D.; MOORE, G.A. Factors affecting Agrobacteriummediated transformation in citrus and production of sour orange (Citrus aurantium L.) plants expressing the coat protein gene of citrus tristeza virus. Plant Cell Reports, v.16, p.745-753, 1997. 
HANDRO, W.; FLOH, E.I.S. Aspectos básicos do controle da morfogênese in vitro. In: TORRES, A.C.; CALDAS, L.S. Técnicas e aplicações da cultura de tecidos de plantas. Brasília; EMBRAPA, 1990. p.203-212.

HERRERA-ESTRELLA, L.; DEPICKER, A.; VAN MONTAGU, M.; SCHELL, J. Expression of chimeric genes transferred into plant cells using a Ti-plasmid derived vector. Nature, v.303, p.209-213, 1983.

HIDAKA, T.; OMURA, M.; UGAKI, M.; TOMIYAMA, M.; KATO, A.; OHSHIMA, M.; MOTOYOSHI, F. Agrobacterium-mediated transformation and regeneration of Citrus spp. from suspension cells. Japanese Journal of Breeding, v.40, p.199-207, 1990.

HOEKEMA, A; HIRSCH, P.R.; HOOYKAAS, P.J.J.; SCHILPEROOT, R.A. A binary vector strategy based on separation of vir and $\mathrm{T}$ region of the Agrobacterium tumefaciens Ti-plasmid. Nature, v.303, p.179-180, 1983.

HOLFORD, P.; HERNADEZ, N.; NEWBURY, H.J. Factors influencing the efficiency of T-DNA transfer during co-cultivation of Antirrhinum majus with Agrobacterium tumefaciens. Plant Cell Reports, v.11, p.196-199, 1992.

HOOD, E.E.; GELVIN, S.B.; MELCHERS, L.S.; HOEKEMA, A. New Agrobacterium helper plasmids for genes transfer to plants. Transgenic Research, v.2, p.208-218, 1993.

HOOYKAAS, P.J.J.; BEIJERSBERGEN, A.G.M. The virulence system of Agrobacterium tumefaciens. Annual Review of Phytopathology, v.32, p.157-179, 1994. 
ILLG, R.D. Variação Somaclonal. In: TORRES, A.C.; CALDAS, L.S. Técnicas e aplicações da cultura de tecidos de plantas. Brasília: ABCTP; EMBRAPA, CNPH, 1990.p. 287-295.

JACQ, B.; LESOBRE, O.; SANGWAN, R.S.; SANGWAN-NORREEL, B.S. Factors influencing T-DNA transfer in Agrobacterium-mediated transformation of sugarbeet. Plant Cell Reports, v.12, p.621-624, 1993.

JAMES, D.J.; URATSU, S.; CHENG, J.; NEGRI, P.; VISS, P.; DANDEKAR, A.M. Acetosyringone and osmoprotectants like betaine or proline synergistically enhance Agrobacterium-mediated transformation of apple. Plant Cell Reports, v.12, p.559$563,1993$.

JEFFERSON, R.A. Assaying chimeric genes in plants: the GUS gene fusion system. Plant Molecular Biology Reporter, v.5, p.387-405, 1987.

KANEYOSHI, J.; KOBAYASHI, S.; NAKAMURA, Y.; SHIGEMOTO, N.; DOI, Y. A simple and efficient gene transfer system of trifoliate orange Poncirus trifoliata Raf.). Plant Cell Reports, v.13, v.541-545, 1994.

KAPILA, J.; De RICKE, R.; VAN MONTAGU, M.; ANGENON An Agrobacteriummediated transient gene expression system for intact leaves. Plant Science, v. 122, p.101-108, 1997.

KLEE, H.J.; HORSCH, R.B.; ROGGERS, S.G. Agrobacterium-mediated plant transformation and its further applications to plant biology. Annual Review of Plant Physiology, v.38, p.467-486, 1987. 
KOBAYASHI, S.; OHGAWARA, T. Production of somatic hybrid plants through protoplast fusion of citrus. Japan Agricultural Research Quartely, v.22, p. 181$188,1988$.

KOBAYASHI, S.; UCHIMIYA, H. Expression and integration of a foreign gene in orange (Citrus sinensis L. Osbeck.) protoplasts by direct DNA transfer. Japanese Journal of Genetics, v.64, p.91-97, 1989.

KOBAYASHI, S.; IKEDA, I.; UCHIMIYA, H. Conditions for high frequency embriogenesis from orange (Citrus sinensis Osb.). Plant, Cell, Tissue and Organ Culture, v.4, p.249-259, 1985.

KOBAYASHI, S.; UCHIMIYA, H.; IKEDA, I. Plant regeneration from 'Trovita' orange protoplasts. Japanese Journal of Breeding, v.33, p.119-122, 1983.

KOBAYASHI, S.; OIYAMA, I.; YOSHINAGA, K.; OHGAWARA, T.; ISHII, S. Fertility in an intergeneric somatic hybrid plant of Rutaceae. HortScience, v.26, p.207-210, 1991.

KOCHBA, J.; SPIEGEL-ROY, P.;SAFRAN, H. Adventive plants from ovules and nucelli in Citrus. Planta, v.106, p.237-245, 1972.

KOCHBA, J.; SPIEGEL-ROY, P.;SAFRAN, H. The effects of auxins, cytokinins and inhibitors on embryogenesis in habituated ovular callus of the 'Shamout'orange (Citrus sinenis Osb.). Zetstchrift fur Pflanzenerhahrung und Bodenkund, v.81, p.2083-288, 1977.

KUNITAKE, H.; KAGAMI, H.; MII, M. Somatic embryogenesis and plant regeneration from protoplasts of 'Satsuma' mandarin (Citrus unshiu Marc.). Scientia Horticulturae, v.47, p.27-33, 1991. 
LEE, Y.W.; JIN, S.; SIM, W.S.; NESTER, E.W. Genetic evidence for direct sensing of phenolic compounds by the Vir A protein of Agrobacterium tumefaciens. Proceedings of the National Academy Sciences of the United States of America, v.92, p.12245-12249, 1995.

LIPP-NISSINEN, K.H. Molecular and cellular mechanisms of Agrobacterium-mediated plant transformation. Ciência e Cultura, v.45, p.104-111, 1993.

LOUZADA, E.S.; GROSSER, J.W.; GMITTER JUNIOR, F.G.; NIELSEN, B.; CHANDLER, J.L.; DENG, X.X.; TUSA, N. Eight new somatic hybrids citrus rootstocks with potential for improved disease resistance. HortScience, v.27, p.10331036, 1992.

LUTH, D.; MOORE, G. Transgenic grapefruit plants obtained by Agrobacterium tumefaciens-mediated transformation. Plant Cell, Tissue and Organ Culture, v.57, p.219-222, 1999.

MAGON, R.; SINGH, B.D. Promotion of adventitious bud regeneration by ABA in combination with BAP in epicotyl and hipocotyl explants of sweet orange (Citrus sinensis L. Osbeck). Scientia Horticulturae, v.63, p.123-128, 1995.

MAHESWARAN, G.; WELANDER, M.; HUTCHINSON, J.F.; GRAHAM, M.W. RICHARDS, D. Transformation of apple rootstock M26 with Agrobacterium tumefaciens. Journal of Plant Physiology, v.139, p.560-568, 1992.

MATHEWS, H.; BHARATHAN, N.; LITZ, R.E.; NARAYANAN, K.R.; RAO, P.S.; BATHIA, C.R. The promotion of Agrobacterium mediated transformation in Antropa belladona L. by acetosyringone. Journal of Plant Physiology, v.136, p.404-409, 1990. 
MENDES, B.M.J.; MOURÃO, F.A.A.; FARIAS, P.C.M.; BENEDITO, V.A. Citrus somatic hybridization with potential for improved blight and CTV resistance. In Vitro Cellular Development Biology-Plant, v. 37, p.490-495, 2001.

MENDES-DA-GLÓRIA. F.J.; MOURÃO FILHO, F.A.A.; CAMARGO, L.E.A.; MENDES, B.M.J. Caipira sweet orange + Rangpur lime: a somatic hybrid with potential for use as rootstock in the Brazilian citrus industry. Genetics and Molecular Biology, v.23, p. 661-665, 2000.

MOORE, G.A. Factors affecting in vitro embryogenesis from undeveloped ovules of mature Citrus fruit. Journal of the American Society for Horticultural Science, v.110, p.6-70, 1985.

MOORE, G.A. In vitro propagation of Citrus rootstocks. HortScience, v.21, p.300-301, 1986.

MOORE, G.A.; JACONO, C.C.; NEIDIGH, J.L.; LAWRENCE, S.D.; CLINE, K. Agrobacterium-mediated transformation of Citrus stem segments and regeneration of transgenic plants. Plant Cell Reports, v.11, p.238-242, 1992.

MOORE, G.A.; JACONO, C.C.; NEIDIGH, J.L.; LAWRENCE, S.D.; CLINE, K. In: BAJAJ, Y.P.S. (Ed) Biotechnology in agriculture and forest- plant protoplasts and genetic engineering IV. Berlin: Springer-Verlag, 1993. p. 194-208.

MOREIRA-DIAS, J.M.; MOLINA, R.V.; GUARDIOLA, J.L.; GARCÍA-LUIS, A. Daylength and photon flux density influence the growth regulator effects on morphogenesis in epicotyl segments of Troyer citrange. Scientia Horticulturae, v.87, p.275-290, 2001. 
MOREIRA-DIAS, J.M.; MOLINA, R.V.; BORDÓN, Y.; GUARDICLA, J.L.; GARCÍA-LUIS, A. Direct and indirect organogenic pathways in epicotyl cuttings of Troyer citrange differ in hormone requirements and in their response to light. Annals of Botany, v.85, p.103-110, 2000.

MOTOMURA, T.; HIDAKA, T.; MOURIGUCHI, T.; AKIHAMA, T.; OMURA, M. Intergeneric somatic hybrids between Citrus and Atalantia or Severinia by electrofusion, recombination of mitochondrial genomes. Breeding Science, v.45, p.309-314, 1995.

MOURA, T.L.; ALMEIDA, W.A.B.; MENDES, B.M.J.; MOURÃO FILHO, F.A.A. Organogênese in vitro de Citrus em função de concentrações de BAP e seccionamento do explante. Revista Brasileira de Fruticultura, v.23, p.240-245, 2001.

MOURÃO FILHO, F.A.A.; GROSSER, J.W.; GMITTER JUNIOR, F.G. New tetraploid breeding parents for triploid seedless citrus development. Fruit Varieties Journal, v.50, p.76-80, 1996.

MOURGUES, F.; CHEVREAU, E.; LAMBERT, C.; De BONDT, A. Efficient Agrobacterium-mediated transformation and recovery of transgenic plants from pear (Pyrus communis L.). Plant Cell Reports, v.16, p.1041-1045, 1996.

MURASHIGE, T.; SKOOG, F. A revised medium for rapid growth and bioassay with tobacco tissue culture. Physiologia Plantarum, v. 15, p.473-497, 1962.

MUKHOPADHYAY, A.; ARUMUGAM, N.; NANDAKUMAR, P.B.A.; PRADHAN, A.K.; GUPTA, V.; PENTAL, D. Agrobacterium-mediated genetic transformation of oildeed Brassica campestris: Transformation frequency is strongly influenced by the mode of shoot regeneration. Plant Cell Reports, v.11, p.506-513, 1992. 
NAM, J.; MATTHYSSE, A.G.; GELVIN, S.B. Differences in susceptibility of Arabidopsis ecotypes to crow gall disease may result from a deficiency in T-DNA integration. The Plant Cell, v.9, p.317-333, 1997.

NESTER, E.W.; GORDON, M.P.; AMASINO, R.M.; YANOFSKY, M.F. Crown gall: a molecular and physiological analysis. Annual Review of Plant Physiology, v.35, p.387-413, 1984.

OHGAWARA, T.; KOBAYASHI, S.; OHGAWARA, E.; UCHIMIYA, H.; ISHII, S. Somatic hybrid plants obtained by protoplast fusion between Citrus sinensis and Poncirus trifoliata. Theoretical and Applied Genetics, v.71, p.1-4, 1985.

OLIVEIRA, R.P.; MENDES, B.M.J.; TULMANN NETO, A. Obtenção e cultura de calos nucelares de limão Cravo, tangerina Cleópatra e Poncirus trifoliata. Revista Brasileira de Fisiologia Vegetal, v.6, p.115-119, 1994.

PASQUAL, M.; ANDO, A. Micropropagação de 'Trifoliata' através da cultura de gemas axilares in vitro. Pesquisa Agropecuá ria Brasileira, v. 24, p.217-220, 1989.

PAWLICKI, N.; SANGWAN, R.S.; SANGWAN-NORREEL, B.S. Factors influencing the Agrobacterium tumefaciens-mediated transformation of carrot (Daucus carota L.). Plant Cell, Tissue and Organ Culture, v.31, p.129-139, 1992.

PEÑA, L.; CERVERA, M.; JUÁREZ, J.; NAVARRO, A.; PINA, J.A.; NAVARRO, L. Genetic transformation of lime (Citrus aurantifolia Swing.): factors affecting transformation and regeneration. Plant Cell Reports, v.16, p.731-737, 1997. 
PEÑA, L.; MARTÍN-TILlO, M.; JUÁREZ， J.; PINA， J.A.; NAVARRO, L.; MARTÍNEZ-ZAPATER, M. Constitutive expression of Arabidopsis LEAFY or APETALA1 genes in citrus reduces their generation time. Nature, v.19, p.263-267, 2001.

PEÑA, L.; CERVERA, M.; JUÁREZ, J.; NAVARRO, A.; PINA, J.A.; DURÁ-VILA, N.; NAVARRO, L. Agrobacterium-mediated transformation of sweet orange and regeneration of transgenic plants. Plant Cell Reports, v.14, p.616-619, 1995a.

PEÑA, L.; CERVERA, M.; JUÁREZ, J.; ORTEGA,C.; PINA, J.A.; DURÁ-VILA, N.; NAVARRO, L. High efficiency Agrobacterium-mediated transformation and regeneration of citrus. Plant Science, v.104, p.183-191, 1995 b.

PÉREZ-MOLPHE-BALCH, E.; OCHOA-ALEJO, N. In vitro plant regeneration of Mexican lime and mandarin by direct organogenesis. HortScience, v.32, p.931-934, 1997.

PÉREZ-MOLPHE-BALCH, E.; OCHOA-ALEJO, N. Regeneration of transgenic plants of Mexican lime from Agrobacterium rhizogenes-transformed tissues. Plant Cell Reports, v.17, p.591-596, 1998.

RANGAN, T.S.; MURASHIGE, T.; BITTERS, W.P. In vitro initiation for nucellar embryos in monoembryonics Citrus. HortScience, v.3, p.226-227, 1968.

SANGWAN, R.S.; BOURGEOIS, Y.; BROWN, S.; VASSEUR, G.; SANGWANNORREEL,B. Characterization of competent cells and early events of Agrobacterium-mediated genetic transformation in Arabidopsis thaliana. Planta, v.188, p.439-456, 1992. 
SARMENTO, G.G.; ALPERT, K.; TANG, F.A; PUNJA, Z.K. Factors influencing Agrobacterium tumefaciens mediated transformation and expression of kanamycin resistance in pickling cucumber. Plant Cell, Tissue and Organ Culture, v.31, p.185-193, 1992.

SAUTON, A.; MOURAS, A.; LUTZ, A. Plant regeneration from citrus root meristems. Journal of Horticultural Science, v. 57, p. 227-231, 1982.

SHEIKHOLESLAM, S.N.; WEEKS, D.P. Acetosyringone promotes high efficiency transformation of Arabidopsis thaliana explants by Agrobacterium tumefacines. Plant Molecular Biology, v.8, p.291-298, 1987.

SIM, G.E.; GOH, C.J.; LOH, C.S. Micropropagation of Citrus mitis Blanco- multiple bud formation from shoot and root explants in the presence of 6-benzylaminopurine. Plant Science, v.59, p.203-210, 1989.

SIMÃO, S. Citrus. In: SIMÃO, S. (Ed.) Tratado de fruticultura. Piracicaba: FEALQ, 1998. p. 419-472.

SOOST, R.K.; CAMERON, J.W. Citrus. In: JANICK, J.; MOORE, J.N. (Ed.) Advances in fruit breeding. West Lafayette: Purdue University Press, 1975. p.507-540.

SPIEGEL-ROY, P.; SAAD, S. Effect of carbohydrates and inhibitors of $\mathrm{GA}_{3}$ biosynthesis on embryogenic potencial of salt tolerant and non-tolerant callus lines of orange (Citrus sinensis Osb.). Plant Science, v.47, p.215-220, 1986.

STACHEL, S.E.; NESTER, E.W. The genetic and transcriptional organization of the vir region of A6 Ti plasmid of Agrobacterium tumefaciens. EMBO Journal, v.5, p.1445-1454, 1986. 
STACHEL, S.E.; MESSENS, E.; VAN MONTAGU, M.; ZAMBRYSKI, P. Identification of the signal molecules produced by wounded plant cells that activate T-DNA transfer in Agrobacterium tumefaciens. Nature, v.318, p.624-629, 1985.

THORPE, T.A. Morphogenesis and regeneration. In: VASIL, I.K.; THORPE, T.A. (Ed.) Plant cell and tissue culture. London: Kluer Academic, 1994. p.17-36.

TINLAND, B. The integration of T-DNA into plant genomes. Trends in Plant Science, v.1, p.178-184, 1996.

TOMAZ, M.L.; MENDES, B.M.J.; MOURÃO FILHO, F.A.A.; DEMÉTRIO, C.G.B.; JANSAKUL, N.; RODRIGUEZ, A.P.M. Somatic embryogenesis in citrus spp.: carbohydrate stimulation and histodifferentiation. In Vitro Cellular Developmental Biology-Plant, v.37, p.446-452, 2001.

VANCANNEYT, G.; SCHMIDT, R.; O'CONNOR-SÁNCHEZ, A.; WILLMITZER, L.; ROCHA-SOSA, M. Construction of an intron-containing marker gene: splicing of the intron in transgenic plants and its use in monitoring early events in Agrobacteriummediated plant transformation. Molecular and General Genetics v.220, p.245-250, 1990.

VAN SLUYS, M.A. Agrobacterium: um vetor natural para transformação em plantas. In: TORRES, A.C.; CALDAS, L.S.; BUSO, J.A. Cultura de tecidos e transformação genética de plantas. Brasília: Embrapa; SPI; CNPH, 1999. p.737759.

VAN SLUYS, M.A.; HASHIMOTO, R.Y.; SCORTECCI, K.C. Gene transfer from Agrobacterium to plants. Ciência e Cultura, v.44, p.296-300, 1992. 
VARDI, A.; BLEICHMAN, S.; AVIV, D. Genetic transformation of citrus protoplasts and regeneration of transgenic plants. Plant Science, v.69, p.199-206, 1990.

VARDI, A.; SPIEGEL-ROY, P.; GALUN, E. Citrus cell culture: isolation of protoplasts, plating densities, effect of mutagens and regeneration of embryos. Plant Science Letters, v.4, p.231-236, 1975.

VARDI, A.; SPIEGEL-ROY, P.; GALUN, E. Plant regeneration from Citrus protoplasts: variability in methodological requirements among cultivars and species. Theoretical and Applied Genetics, v.62, p.171-176, 1982

VICEDO, B.; LÓPEZ, M.J.; ASÍNS, M.J.; LÓPEZ, M.M. Spontaneous transfer of the Ti plasmid of Agrobacterium tumefaciens and the nopaline catabolism plasmid of A. radiobacter strain K84 in crown gall tissue. Phytopathology, v.36, p. 528-534, 1996.

VILLEMONT, E.; DUBOIS, F.; SANGWAN, R.S.; VASSEUR, G.; BOURGEOIS, Y.; SANGWAN-NOREEL, B.S. Role of the cell cycle in the Agrobacterium-mediated genetic transformation of Petunia: evidence of an S-phase control mechanism for TDNA transfer. Planta, v.201, p.160-172, 1997.

VU, J.C.V.; NIEDZ, R.P.; YELENOSKY, G. Glycerol stimulation of chlorophyll synthesis, embriogenesis, and carboxylation and sucrose metabolism enzymes in nucellar callus of 'Hamlin' sweet orange. Plant Cell, Tissue and Organ Culture, v.33, p.75-80, 1993.

WANG, K.; HERRERA-ESTRELLA, L.; VAN MONTAGU, M.; ZAMBRYSK, P. Right 25bp terminus of the nopaline T-DNA is essential for and determines direction of DNA transfer from Agrobacterium to the plant genome. Cell, v.38, p.455-462, 1984. 
WEISING, K.; KAHL, G. Natural genetic engineering of plants cells: the molecular biology of crown gall and hairy root disease. World Journal of Microbiology \& Biotechnology, v.12, p. 327-351, 1996.

YANG, Z.N.; INGELBRECHT, I.L.; LOUZADA, E.; SKARIA, M.; MIRKOV,T.E. Agrobacterium-mediated transformation of the commercially important grapefruit cultivar Rio Red (Citrus paradisi Macf.) Plant Cell Reports, v.19, p.1203-1211, 2000.

YAO, J.L.; WU, J.H.; GLEAVE, AP.; MORRIS, B.A.M. Transformation of citrus embryogenic cells using particle bombardment and production of transgenic embryos. Plant Science, v.113, p.175-183, 1996.

ZAMBRYSKI, P.C. Chronicles from the Agrobacterium-plant cell DNA transfer story. Annual Review of Plant Physiology and Plant Molecular Biology, v.43, p.465490, 1992.

ZAMBRYSKI, P.C.; TEMPÉ, J.; SCHELL, J. Transfer and function of T-DNA genes from Agrobacterium Ti and Ri plasmids into plants. Cell, v.56, p.193-201, 1989.

ZAMBRYSKI, P.C.; JOOS, H.; GENETELLO, C.; LEEMANS, J.; VAN MONTAGU, M.; SCHELL, J.S. Ti plasmid vector for introduction of DNA into plant cells without alteration of their normal regeneration capacity. EMBO Journal, v.2, p.2143-2150, 1983.

ZHANG, F.L.; TAKAHATA, Y.; WATANABE, M.; XU, J.B. Agrobacterium-mediated transformation of cotyledonary explants of Chinese cabbage (Brassica campestris L. ssp. Pekinensis). Plant Cell Reports, v. 19, p.569-575, 2000. 
ZUPAN, J.; ZAMBRYSKI, P. The Agrobacterium DNA transfer complex. Critical Reviews in Plant Sciences, v.16, p. 279-295, 1997. 